NBER WORKING PAPER SERIES

\title{
THE FOUNDING OF THE FEDERAL RESERVE, THE GREAT DEPRESSION AND THE EVOLUTION OF THE U.S. INTERBANK NETWORK
}

\author{
Matthew S. Jaremski \\ David C. Wheelock \\ Working Paper 26034 \\ http://www.nber.org/papers/w26034 \\ NATIONAL BUREAU OF ECONOMIC RESEARCH \\ 1050 Massachusetts Avenue \\ Cambridge, MA 02138 \\ July 2019
}

The authors thank Dan Bogart, Charles Calomiris, and two anonymous referees for comments on a previous version of this paper, as well as conference participants at the Federal Reserve Bank of Cleveland's 2018 Financial and Monetary History Workshop and the 2018 World Economic History Conference. The paper greatly benefited from a grant from the Yale Economic Growth Center. The views expressed in this paper are those of the authors and do not necessarily reflect official positions of the Federal Reserve Bank of St. Louis, the Federal Reserve System, or the National Bureau of Economic Research.

NBER working papers are circulated for discussion and comment purposes. They have not been peer-reviewed or been subject to the review by the NBER Board of Directors that accompanies official NBER publications.

(C) 2019 by Matthew S. Jaremski and David C. Wheelock. All rights reserved. Short sections of text, not to exceed two paragraphs, may be quoted without explicit permission provided that full credit, including $\odot$ notice, is given to the source. 
The Founding of the Federal Reserve, the Great Depression and the Evolution of the U.S. Interbank Network

Matthew S. Jaremski and David C. Wheelock

NBER Working Paper No. 26034

July 2019

JEL No. G21,L14,N22

\section{ABSTRACT}

Financial network structure is an important determinant of systemic risk. This paper examines how the U.S. interbank network evolved over a long and important period that included two key events: the founding of the Federal Reserve and the Great Depression. Banks established connections to correspondents that joined the Federal Reserve in cities with Fed offices, initially reducing overall network concentration. The network became even more focused on Fed cities during the Depression, as survival rates were higher for banks with more existing connections to Fed cities, and as survivors established new connections to those cities over time.

Matthew S. Jaremski

Utah State University

Department of Economics and Finance

3565 Old Main Hill

Logan, UT 84322

and NBER

matthew.jaremski@usu.edu

David C. Wheelock

Research Division

Federal Reserve Bank of St. Louis

P.O. Box 442

St. Louis, MO 63166-0442

david.c.wheelock@stls.frb.org 


\title{
The Founding of the Federal Reserve, the Great Depression and the Evolution of the U.S. Interbank Network
}

\author{
Abstract \\ Financial network structure is an important determinant of systemic risk. This \\ paper examines how the U.S. interbank network evolved over a long and \\ important period that included two key events: the founding of the Federal \\ Reserve and the Great Depression. Banks established connections to \\ correspondents that joined the Federal Reserve in cities with Fed offices, initially \\ reducing overall network concentration. The network became even more focused \\ on Fed cities during the Depression, as survival rates were higher for banks with \\ more existing connections to Fed cities, and as survivors established new \\ connections to those cities over time.
}

\section{Introduction}

The interconnected nature of financial networks can propagate shocks, increase systemic risk, and magnify economic downturns. A growing literature finds that contagion in networks of interlinked financial institutions was important during recent and historical financial crises (e.g., Puhr, Seliger, and Sigmund 2012; Cohen-Cole, Patacchini, and Zenou 2016; Calomiris and Carlson 2017; Mitchener and Richardson 2019). Insights from theoretical studies suggest that the tendency of interbank networks to amplify shocks reflects the relative size of network members, the extent of interconnections between them, and the magnitude of shocks hitting the system, whereas the systemic risk posed by individual institutions depends on heterogeneity in network structure and the concentration of counterparty exposures (Cont, Moussa, and Santos 2013). Prominent in this literature is the idea that greater interconnectedness can make networks "robust-yet-fragile" (e.g., Allen and Gale 2007; Acemoglu, Ozdaglar, and Tahbaz-Salehi 2015). 
Specifically, greater interconnectedness makes an interbank network more resilient to relatively minor shocks, but can be destabilizing if adverse shocks are sufficiently large to eliminate the excess liquidity of the banking system. This is especially true for core-periphery systems that have a small number of well-connected banks at the center of the network, including those of Germany (Craig and von Peter 2014), the United Kingdom (Gai, Haldane, and Kapadia 2011), and the United States. ${ }^{1}$

Although studies suggest that network structure affects systemic risk, there has been relatively little empirical work on how the structures of interbank networks evolve. Using newly digitized data on the entire U.S. interbank network in 1900, 1910, 1919, 1929, and 1940, this paper studies how the network evolved over a relatively long and important period in U.S. financial history that included two key events: the founding of the Federal Reserve (Fed) and the Great Depression. Both events seem likely to have produced lasting changes in the structure of the interbank network. The founding of the Fed established a lender of last resort and new federal banking regulator, a new structure of reserve requirements, and a new payments provider. The Great Depression eliminated some one-third of U.S. banks and led to further substantive changes in bank regulation. By examining quantitatively how the network evolved over the first forty years of the $20^{\text {th }}$ century, we can confirm a long-established, but largely descriptive understanding of the interbank network and study how the network evolved following these two key events. ${ }^{2}$

\footnotetext{
${ }^{1}$ Other theoretical studies of the channels through which networks can transmit shocks include Allen and Gale (2000), Dasgupta (2004), Allen and Babus (2009), and Freixas, Parigi, and Rochet (2000).

${ }^{2}$ Descriptive studies of the interbank network and correspondent system include Watkins (1929) and Myers (1931), and more recently James (1978) and James and Weiman (2010).
} 
Historical studies have used detailed micro-level data on interbank connections in specific locations or short periods in research on banking panics, contagion, and local economic development. ${ }^{3}$ However, other than our paper, only Das, Mitchener, and Vossmeyer (2018) use data on the entire network for even a single year. Data on the connections of all banks is vital to understanding the structure of the network. By digitizing the connections of all banks, we are able to identify the largest correspondent banks and most prominent cities, and thereby provide a complete picture of the network's structure. Thus, whereas descriptive studies have provided a general picture of the network and those based on small samples have quantified pieces of the network, we are the first to document the entire structure of the network for any time before the Great Depression or to provide quantitative evidence on how the structure evolved over time.

Our paper relates closely to studies focusing on how changes in regulation and financial crises can affect the formation and structure of interbank networks. Such studies include Paddrik, Anderson, and Wang (2019), who examine how the interbank network responded to the major regulatory changes introduced by the National Banking Acts of the 1860s. Based on a sample of Pennsylvania banks, they find that the Acts led to an increase in network concentration and potentially systemic risk by encouraging banks to shift their interbank relationships to correspondent banks in New York City and Chicago. Das, Mitchener, and Vossmeyer (2018)

\footnotetext{
${ }^{3}$ Examples include Odell and Weiman (1998), who use information about interbank connections among Georgia and Texas banks in 1880, 1900, and 1910; Redenius (2002), who studies connections among Indiana and Georgia banks before 1910; Calomiris and Carlson $(2016,2017)$, who examine connections of national banks in 38 regional centers during the early 1890s; Paddrik, Anderson, and Wang (2019), who use data for Pennsylvania banks in the 1860s; Carlson, Mitchener, and Richardson (2011), who study the transmission of distress among Florida banks during Great Depression; and Heitfield, Richardson, and Wang (2017), who use interbank data for Tennessee, Mississippi and Alabama to study contagion in 1930.
} 
consider the impact of Great Depression-era bank failures on the interbank network. They present several descriptive measures of the entire U.S. interbank network in 1929 and 1934 and find that the systemic risk of the system, and particularly the risk posed by the very largest banks, increased during the early Great Depression. We build on these studies by investigating how the founding of the Fed and the Great Depression affected the distribution of network connections among banks and cities with different characteristics. In particular, we examine how the Fed's founding affected the types of correspondents and cities that banks chose to connect to as well as whether the changes in the network observed during the Depression continued or interrupted any trends in network evolution that began with the Fed's founding.

Our study also provides context and support for the range of papers that study interbank contagion during the Great Depression and other periods. For instance, Richardson (2007) shows that the failure of Caldwell and Company in 1930 contributed to the demise of many other banks through their interbank connections. Carlson, Mitchener, and Richardson (2011) show that correspondent relationships transmitted distress among Florida banks during a crisis in 1929, and Richardson and Van Horn (2018) show that international connections were important for spreading risk to New York during the Depression. Das, Mitchener, and Vossmeyer (2018) show that network risk measures help predict bank survival to 1934, and Calomiris, Jaremski, and Wheelock (2019) find that during the Depression, banks were vulnerable to closures of their correspondents. Whereas these studies all take network structure as given, our focus here is on how the structure evolved over the three decades before the Great Depression and how it changed during the Depression, and in this way, we provide a long-run perspective that can help inform future studies of network contagion. 
The data confirm that the U.S. interbank network at the end of the nineteenth century was pyramidal in structure with a small number of banks serving as correspondents for a high percentage of the nation's banks. Nearly every bank deposited funds in at least one other bank, yet very few banks held funds for other banks. By far, the banks with the most connections were large national banks located in New York City, and most U.S. banks had at least one New York City correspondent.

We find, however, that the network became less concentrated after the establishment of the Federal Reserve System as banks shifted their correspondent relationships away from New York City toward banks in other cities - especially cities with Federal Reserve offices within their local Fed district. Federal Reserve member banks located in Fed cities were especially favored as correspondents because of their unique access to Federal Reserve liquidity and payments services, which they were able to pass through to other member and non-member banks (Anderson, Calomiris, Jaremski, and Richardson 2018). The relative decline in focus on New York City after the Fed's establishment occurred despite other trends in the financial system that favored New York City banks, including the tremendous growth of U.S. securities markets and international trade after World War I. Thus, the Fed not only served as a direct alternative to private correspondent banks, but its founding changed the relative attractiveness of correspondents in different locations and seems to have overshadowed other forces that would likely have increased network concentration.

Reduced network concentration meant that the risk of contagion emanating from a crisis hitting a core city, as in the Panic of 1907, was somewhat lessened. However, the system remained vulnerable to local and regional panics, and ultimately depended on the individual Federal Reserve Banks to respond to those events to prevent them from spreading across the 
banking system. ${ }^{4}$ The Fed's failure to prevent or stem the panics of the Great Depression, which mainly arose outside the central money markets, enabled full-blown banking crises to spread through the interbank system. Withdrawals of interbank deposits led correspondent banks to reduce lending (Mitchener and Richardson 2019), and banks whose correspondents closed were themselves at higher risk of closing. In the wake of this distress, banks increased their connections to correspondents in cities with Federal Reserve Banks and branches even though, on average, those cities did not have lower rates of bank closure than other large cities. Banks were also more likely to link to Fed member banks, which had lower failure rates during the Depression and could provide access to Federal Reserve liquidity.

\section{Background on the Interbank Network}

The U.S. developed a deep and active interbank network in the nineteenth century. As a result of legal restrictions on branch banking, the banking system was comprised of thousands of small, unit banks that depended on relationships with banks in major cities for payments services, securities transactions, and to manage seasonal imbalances between local deposits and local loans. Interbank relationships consisted primarily of account agreements between banks. Each connection involved a bank and a correspondent in which the bank maintained a deposit. Following convention, we refer to the banks that held deposits with a given correspondent bank as the correspondent's respondents.

Banks established connections with correspondents for three main reasons. First, most banks could use correspondent deposits to satisfy a portion of their legal reserve requirements

\footnotetext{
${ }^{4}$ Davison and Ramirez (2014) show that local banking panics were common during the 1920s. Carlson, Mitchener and Richardson (2011) describe how the Federal Reserve Bank of Atlanta successfully ended a panic in Florida in 1929, and Richardson and Troost (2009) show that the impact of Great Depression panics on local economic conditions depended on the responsiveness of individual Federal Reserve Banks to them.
} 
and received interest on those deposits until prohibited by the Banking Act of 1933. Second, banks invested surplus funds with and obtained loans from their correspondents. Third, banks relied on correspondents for payments services. In particular, correspondent banks typically cleared any checks, drafts, and notes drawn on banks in its city or any other bank in its network and deposited the proceeds into the respondent's account.

The interbank system was large in terms of total deposits and relative to banking system assets. Shown in Figure 1, deposits "due from banks and Fed" (i.e., funds held by banks on deposit in correspondent banks or Federal Reserve Banks) totaled roughly \$2 billion in 1914 (in constant 1900 dollars), $\$ 2.5$ billion in 1929 , and topped out at more than $\$ 12$ billion in 1940. All of the net increase between 1914 and 1929 reflected balances held with Federal Reserve Banks rather than with commercial bank correspondents. Deposits "due to banks" represent funds held by correspondent banks for the accounts of their respondents, and exclude balances that banks held with the Fed. Total interbank deposits held in correspondent banks changed little (in inflation-adjusted dollars) between 1914 and 1929, and declined from about 10 percent of total banking system assets to 5 percent, while deposits held at the Fed rose to about $\$ 500$ million (in 1900 dollars). However, both deposits with correspondent banks and deposits with the Fed rose substantially during the 1930s, in dollar terms and as a percentage of total banking system assets.

The banking system depended on a well-functioning interbank network. However, the network tended to break down and become a source of instability when hit by run-inducing shocks. Shocks to banks in core cities, especially New York City, sometimes produced major panics that reverberated throughout the banking system, as in the Panics of 1873 and 1907, as did shocks that originated in areas outside of the central money markets, as in the Panic of 1893. In panics, banks were unable to access their funds when their correspondents suspended 
withdrawals, causing the panic to spread across the system via the interbank network (Sprague 1910; Wicker 2000; Gorton and Tallman 2018).

Inspired by National Monetary Commission's study of U.S. and international banking systems after the Panic of 1907, the Federal Reserve Act of 1913 sought to reduce, if not eliminate, the banking system's reliance on the interbank network and concentration of the nation's bank reserves in New York City. The Fed's decentralized structure consisting of 12 quasi-independent Reserve Banks serving distinct regional districts reflected a desire to minimize control of the nation's financial system by the major New York City banks. The Federal Reserve Act required banks with federal charters (i.e., national banks) to become members of the Federal Reserve System and hold reserves in a regional Federal Reserve Bank (state-chartered banks could also become members but were not required to do so). The Reserve Banks, which opened in November 1914, offered payments services and liquidity to their members through discount window loans.

Banks responded to the establishment of a lender of last resort by substantially reducing their own liquidity (Carlson and Wheelock 2018; Calomiris, Jaremski, and Wheelock 2019). By lending to banks through its discount window, the Fed largely eliminated seasonal tightness in money markets, which had long been associated with banking panics (Miron 1986; Bernstein, Hughson, and Weidenmier 2010; Carlson and Wheelock 2016, 2018). The nation's banks continued to rely on interbank connections for services that the Fed did not provide, however, such as a conduit for investing in securities markets (Watkins 1929). The Great Depression resulted in still more changes in the network's structure, both as a consequence of bank failures and of changes in the correspondent ties of banks that survived the Depression. 
The historical record makes clear the reasons why the interbank network arose organically in the United States and how it transmitted financial disturbances across the banking system. However, as discussed in the introduction, the existing literature's focus on small samples of banks and time periods has not provided a full account of the network's structure at a particular point in time or how the structure evolved over time in response to the establishment of the Federal Reserve System or the Great Depression. The rest of this paper examines comprehensive bank- and city-level information on interbank connections for a broader understanding of how the nation's network changed in response to these two key events.

\section{Interbank Network Data and Macro Facts}

To provide a comprehensive view of the U.S. interbank network at different points in time, we digitized the correspondent relationships published by the Rand McNally Bankers' Directory in 1900, 1910, 1919, 1929, and 1940. The directories claim to provide "a full and complete list of banks, bankers and savings banks in the United States" (1899, title page) as well as each bank’s "principal correspondents." While giving no definition of principal correspondents, the evidence suggests that the Directory attempted to capture the largest and most important correspondents. From the few surviving archival records that contain full correspondent information for comparison, we determined that by 1900 the correspondent lists in Rand McNally covered the vast majority of funds placed in correspondents. In addition to providing a source for identifying the correspondents of every bank, the information allows us to identify every bank's respondents. ${ }^{5}$

\footnotetext{
${ }^{5}$ The earliest editions of Rand McNally Bankers' Directory only listed correspondents in New York City or in the largest nearby financial center. Coverage increased over time and it appears that by 1900 most correspondents were included. Directories include listings of private banks, and bank branches as well as commercial banks, mutual savings banks and institutions, and trust companies. We focus on chartered depository institutions and as such omit
} 
We chose to digitize years that enable us to study the evolution of the interbank market across three distinct regimes. Specifically, 1900 and 1910 provide a view of the network before the establishment of the Federal Reserve in 1914, while the years 1919 and 1929 cover the early Federal Reserve period. Finally, by comparing data for 1929 and 1940, we obtain a view of how the network changed during the Great Depression. ${ }^{6}$

When describing the U.S. interbank network, we find it helpful to measure network concentration and establish other facts about the network in each year before examining patterns in the underlying interbank connections. Shown in Table 1, most banks had more than one correspondent. The average number of correspondents per bank rose from 2.3 in 1900 to 3.2 in 1940. However, while most banks had multiple correspondents, relatively few had any respondents. That is, few banks were correspondents of other banks. In each year, close to 90 percent of banks had no respondents and 5-8 percent had only one or two. Fewer than one-half percent of banks had more than 150 respondents. Therefore, while nearly every bank participated in the network, only a handful of banks were network hubs linking together large numbers of banks.

Table 2 lists the 10 banks with the largest number of respondents in each year, as well as the percentage of U.S. banks that were directly connected to at least one of the top 10 banks. Clearly, the U.S. interbank system was highly concentrated. In 1900, for example, 14.7 percent

(1) private banks (i.e., unincorporated financial institutions with no charters or regulation) because they typically were small and did not always take deposits, and (2) bank branches because they either mimicked their head office's correspondents or did not list any. We also omit the less than 1 percent of banks that did not list any correspondents as we are unsure whether the data are missing or that those banks actually had no correspondents.

${ }^{6}$ We chose 1919, rather than 1920, to avoid the post-World War I recession that began in 1920, and 1929, rather than 1930, to capture the network on the eve of the Great Depression. 
of all U.S. banks (1,465 banks) were respondents of the top correspondent bank (Hanover National Bank of New York), while 53.8 percent of all banks (6,984 banks) were respondents of at least one of the top correspondent banks. The banks with hundreds or thousands of respondents had the greatest potential for contributing to systemic risk in the interbank network. ${ }^{7}$ The percentage of banks connecting to the top correspondent banks varied somewhat over time. The percentage connecting to the top bank declined from 14.8 percent in 1910 to 13 percent in 1919, but then rose over the subsequent two decades, reaching 21.4 percent in 1940. The percentage of banks connecting to any of the top 10 increased from 53.8 percent in 1900 to 59.9 percent in 1910 , then fell to 53.1 percent in 1929 before rising to 56.8 percent in 1940 . Thus, these measures indicate that while concentration remained high throughout the period, it declined somewhat over the first decade and half after the founding of the Federal Reserve but increased during the Great Depression.

The information in Table 2 also shows that New York City and Chicago banks were always among the most highly connected. For instance, in 1900, seven of the top 10 correspondent banks were located in New York City and two were located in Chicago, whereas in 1940, six of the top 10 were in New York City and one was in Chicago. Table 3 lists the 10 cities with the largest number of respondent connections in each year. As suggested by the

\footnotetext{
${ }^{7}$ The literature on networks generally views concentration as one of the most important factors affecting the potential transmission of risk through a network (e.g., Acemoglu, Ozdaglar, and Tahbaz-Salehi 2015; Das, Mitchener and Vossmeyer 2018). Of course, the extent to which a given correspondent bank contributed to systemic risk depended also on the share of its liabilities comprised of interbank deposits, and its capital and liquidity buffers, all of which play a part in determining the potential loss to the network if the bank were to fail. Unfortunately, however, data on interbank assets and liabilities are not available in published balance sheets for individual banks after 1928, which would necessarily make any estimates of systemic risk imprecise.
} 
previous tables, U.S. banks were highly connected to New York City and, to a lesser extent, Chicago.

Although New York City and Chicago remained the largest network hubs, the percentage of banks with a New York City correspondent declined after 1900, when 85.2 percent of all U.S. banks had at least one New York City correspondent. Substantial numbers of new banks opened during the first two decades of the twentieth century, especially in the Midwest, South, and West. Many of them connected to correspondents in regional banking centers, such as Kansas City, Minneapolis, and Chicago, rather than New York. Between 1900 and 1919, the fraction of banks located in the Northeast declined from 23.1 percent to 13.8 percent, and the percentage of banks with a New York City correspondent declined to 63.7 percent. ${ }^{8}$ Failures and mergers eliminated hundreds of banks during the 1920s, however, especially in the regions that had seen rapid growth during the previous two decades. The fraction of banks located in the Northeast rose to 17.4 percent in 1929 , but in spite of this, the percentage of banks with a New York City correspondent continued to fall, down to 63.0 percent in 1929 . Thus, something other than a shift in the geographic mass of the banking system — likely the establishment of the Federal Reserve - must have influenced where banks chose to establish correspondent ties during the 1920s. During the Depression, both the percentage of banks with a New York City correspondent and the fraction of banks located in the Northeast rose. By 1940, 21.6 percent of banks were located in the Northeast and 74.8 percent of all banks had a New York City correspondent. Coinciding with the shift in correspondent connections away from New York City between 1900 and 1929, the percentage of total interbank connections to any of the top 10 cities also declined, from 95.5 percent in 1900 to just 83.8 percent in 1929 . As we show later, the

\footnotetext{
${ }^{8}$ The regional bank aggregates in this section are from Board of Governors of the Federal Reserve System (1959).
} 
decline among the top 10 cities occurred as banks established ties to correspondents in Federal Reserve Bank and branch cities in their own Fed districts.

The number of banks that have a correspondent in a given city and the number of links to correspondents in a city are two measures of the importance of a city to the nation-wide network. However, those measures do not reflect the overall centrality of a city to the network, which depends not only on the number respondents a city's banks have, but also the number and importance of correspondent connections that the city's banks have to other cities. A city whose banks have correspondents that are themselves well-connected will be more central to the network, and hence likely to pose more systemic risk, than a city whose banks are connected to correspondents with few other connections. Therefore, we augment the basic statistics with three additional measures of network centrality at the city-level: degree, eigenvector, and betweenness centrality. ${ }^{9}$

Degree centrality measures the percentage of other cities to which a given city is directly connected through either correspondent or respondent connections. Eigenvector centrality reflects the collective importance of the banks in a particular city to the network based on 1) their direct interbank connections to banks in other cities and 2) the relative importance of the banks in the latter cities to the network. A city with a given number of connections to fringe cities (i.e., those with few connections) would receive a lower score than a city with a similar number of connections to important cities (i.e., those with many connections). Betweenness centrality is a measure based on the paths by which all cities are connected. Specifically, after calculating the shortest path between every pair of cities, betweenness centrality is the percentage of total shortest paths that cross through a particular city. A city with a high betweenness centrality score

\footnotetext{
${ }^{9}$ See Newman (2008) for additional discussion of these network measures.
} 
thus sits in the middle of the network between a large number of city pairs, but does not have to be directly connected to a large number of cities itself.

Table 4 reports the mean centrality scores for all cities in 1900 (expressed as a percentage), and changes in centrality scores across each decade. ${ }^{10}$ Shown individually are the scores for the 12 Federal Reserve Bank cities, the average score for cities with branches of a Federal Reserve Bank, and the average score for the 100 most populated cities with no Federal Reserve office. As might be expected with a large number of cities and a highly concentrated, hierarchical system, the mean centrality scores for all three measures are quite low, indicating that relatively few cities were important network hubs. The scores for the three central reserve cities_-New York City, Chicago, and St. Louis — are higher than those of other Federal Reserve cities before the Fed was established, and New York City and Chicago have by far the highest scores throughout the years spanned by our data, reflecting their importance to the network throughout the period. ${ }^{11}$

Because the results are similar across the various measures, we focus on eigenvector centrality, which is the most commonly used measure in network and contagion studies because it emphasizes direct connections in measuring the relative importance of highly connected cities. Bank closures in one city were likely to stress banks in cities with direct interbank connections to that city, and thereby spread across the system. Eigenvector centrality captures the importance of first order contagion that could originate from the bank closures in a particular city.

\footnotetext{
${ }^{10}$ We normalize the eigenvector centrality scores to sum to 100 in each year in order to obtain a unique score for each city. Because the scores of most cities are quite small, in Table 4, we report the scores as percentages. Thus, for example, we report New York City's 1900 score (1.2453) as 124.53\%. The changes reported in the table are simple changes in the scores again expressed as percentages (not percentage changes in the scores).

${ }^{11}$ The centrality scores for 1910, 1919, and 1929 and 1940 are reported in Appendix Table A1.
} 
The eigenvector centrality scores for nearly all cities declined between 1900 and 1910, likely because of the large increase in the number of banks, especially in small towns and rural locations. The Gold Standard Act of 1900 halved the minimum capital level for national banks in smaller cities, from $\$ 50,000$ to $\$ 25,000$, which in turn prompted many states to cut the minimums required for state-chartered banks. The number of banks in the United States as well as the number of cities with at least one bank approximately doubled between 1900 and 1910 (Table 1). Many of the new banks were quite small and most established their first correspondent links to banks in nearby cities, rather than to banks in distant financial centers.

The eigenvector centrality scores for New York City, St. Louis, and Philadelphia also fell between 1910 and 1919. However, the scores for other cities with Federal Reserve Banks and branches rose, indicating that they had become more important to the network. Shown in the top panel of Figure 2, Federal Reserve Bank and branch cities generally had the largest increases in eigenvector centrality over the 1910s; most other cities experienced either a decline or a small increase. Indeed, among Fed cities, the increases in eigenvector centrality were negatively correlated with their scores at the beginning of the decade. Northeastern Fed cities generally had small increases in centrality, but cities that were somewhat surprising choices for Reserve Banks, such as Cleveland, Richmond, and Dallas as well as small branch cities such as Seattle, Helena, and Omaha had large increases. ${ }^{12}$

The increased centrality of Fed cities, particularly those that were not previously important, occurred despite other changes in the banking system that would have tended to reduce centrality scores for all major cities. In particular, the growth of the banking system over

\footnotetext{
${ }^{12}$ Jaremski and Wheelock (2017) examine the selection of cities for Reserve Banks and branches and discuss the more controversial selections.
} 
the 1910s would have tended to dilute connections to established cities and thereby lower their centrality scores. The scores of most Fed cities increased, however, and by substantially more than did the scores of most other large cities, suggesting that the presence of the Fed, rather than an increased preference of banks for correspondents in large cities, drove the reorientation of the network toward locations with Fed offices. The decline in the centrality of New York City, which occurred despite tremendous growth of securities markets and international trade during and after World War I, and New York banks’ increased share of national bank assets and deposits after the Fed's founding, is further evidence that the establishment of the Fed was the dominant cause of the network reorientation. The active involvement of all 12 Reserve Banks in the marketing and distribution of Liberty Bonds in their districts may have also contributed to the shift away from New York City toward other Fed cities. ${ }^{13}$

Eigenvector centrality scores for many cities with Federal Reserve Banks and branches also increased substantially between 1929 and 1940 relative to those of other large cities, indicating that Fed cities became even more central to the network during the Depression. While the centrality scores of nearly all large cities increased during the 1930s, it is clear from the bottom panel of Figure 2 that scores for Fed cities generally increased the most. To some extent, the overall increase in concentration reflected a decline in the number of cities with a bank in operation, though as we show below, the main explanation seems to be that banks increased their connections to Federal Reserve cities at the expense of other cities. The next section examines patterns in the network connections of banks and correspondents with particular characteristics

\footnotetext{
${ }^{13}$ Myers (1931) describes the emergence of New York City as the nation's principal money market during the nineteenth century and the importance of the City's banks in government finance.
} 
for additional insights about how the founding of the Fed and the Great Depression reshaped the network.

\section{Micro-Level Network Statistics}

Next, we examine patterns in the correspondent choices of individual banks. As noted previously, on average, banks had between two and four correspondents. Shown in Table 5, the vast majority of correspondent links were to national banks. For example, in 1900, nearly 90 percent of all links were to a national bank, whereas in 1929 and 1940, 72 percent of links were to national banks. The increased percentage of links to state-chartered institutions after 1910 was entirely due to growth in the percentage of links to state-chartered trust companies that joined the Federal Reserve System. The vast majority of trust companies with respondents were Federal Reserve members, and several trust companies were among the top 10 correspondents in 1940 (Table 2). Correspondent banks and trust companies were also disproportionately located in financial centers. More than 75 percent of all links were to banks (or trust companies) located in cities with Federal Reserve Banks or branches. In the following subsections, we examine changes in bank-level connections over time to provide additional clarity about the patterns we observe in the broader statistics, focusing in particular focusing on the effects of the establishment of the Federal Reserve and the Great Depression

\subsection{Establishment of the Federal Reserve}

The Federal Reserve Act brought about the most fundamental regulatory changes of the period between the National Banking Acts of the 1860s and the Great Depression. The centrality measures reported above indicate that the cities that received Federal Reserve Banks or branches became more central to the network. Here, we examine how other aspects of the network's 
structure changed after the Fed was established and present evidence consistent with the founding of the Fed being the main driver of changes in the network.

The Fed's presence seems to have caused a distinct shift in where surviving banks chose to have correspondents. In Table 5, we report the percentages of all correspondent links that were to i) any city with a Fed office, ii) each of the three Fed cities that were central reserve cities from the National Banking era (New York City, Chicago, and St. Louis), and iii) all other Fed cities. We also report the average percentage of each bank's correspondent links that were to banks located in cities with Fed offices in the given bank's Federal Reserve district. In 1900 and 1910, more than half of all correspondent connections were to banks in New York, Chicago, and St Louis. However, that percentage had dropped to 39.2 percent by 1919, and by 1940, only 37.6 percent of all correspondent ties were to banks in the three cities. At the same time, the percentage of links to banks in other Federal Reserve Bank and branch cities rose, from 31.0 percent in 1900 to 36.1 percent in 1919 and 40.7 percent in 1940. The relative declines of New York, Chicago, and St. Louis are not surprising because the Federal Reserve Act eliminated the ability of national banks to use deposits in a reserve or central reserve city bank to satisfy a portion of their reserve requirements.

The Fed's establishment enhanced the ability of banks to obtain payments services and liquidity from correspondents located in their regional Fed offices, thereby reducing the need to have connections in New York City. The percentage of the average bank's links that were to cities with Fed offices within the bank's Fed district increased from 38.3 percent in 1910 to 46.0 percent in 1940. This redistribution contributed to a decline in the average distance from banks to their correspondents from 404 miles in 1910 to 233 miles in 1940. The increase in the percentage of links to cities with Fed offices within a bank's district suggests that the geographic 
redistribution of correspondent relationships reflected the structure of the Federal Reserve System, rather than simply a desire of banks to diversify their correspondent connections across large cities. ${ }^{14}$

Fewer than 1,750 of the more than 19,000 state bank and trust companies in existence during our sample period ever joined the Federal Reserve System. However, many of those that did join experienced large increases in their share of correspondent links. This was especially true for trust companies. In 1940, for example, 24.5 percent of all correspondent links were to trust companies, and 95 percent of those links were to members of the Federal Reserve System. This suggests that the ability to receive liquidity indirectly through member banks likely encouraged banks to establish links to member banks, especially those located in cities with Fed offices. Membership conveyed advantages, including access to the Fed's discount window and payments services, which made member banks attractive as correspondents. Indeed, Anderson, Calomiris, Jaremski, and Richardson (2018) show that New York state banks that already were established correspondent banks were more likely to join the Fed, and gained even more business by doing so. Our data confirm this finding more generally.

In Table 6, we present additional evidence about changes in correspondent relationship patterns, focusing on sets of banks that survived from 1910 to 1919 and from 1910 to 1929 . Focusing on banks that were present in both the first and last years of each interval helps indicate whether the changes in the aggregate statistics reported in Table 5 reflect changes in the

\footnotetext{
${ }^{14}$ Jaremski and Wheelock (2017) show that a survey of national banks was highly influential in determining the boundaries of Federal Reserve districts and selection of cities for Federal Reserve office. The results of that survey, in turn, largely reflected pre-existing correspondent links. Hence, while the cities where Federal Reserve offices were located were already relatively important nodes of the interbank system, they became even more important after the Fed was established.
} 
preferences of banks for the types and locations of correspondents, and not merely the entry or exit of banks and correspondents. ${ }^{15}$

The evidence reported in Table 6 supports and extends the evidence reported in Table 5 for all banks. Across both windows (1910-19 and 1910-29) and all bank types, we observe a shift of correspondent ties toward Fed member banks located in cities with Fed offices in a bank's district. ${ }^{16}$ Additionally, the table shows that the average number of respondents per bank increased substantially for banks that joined the Federal Reserve System. For example, the average number of respondents among Fed member state banks and trust companies rose from 2.9 in 1910 to 6.3 in 1919, whereas the average number of respondents for other state banks and trust companies was small throughout the period, though it did rise from 0.09 in 1910 to 0.25 in 1919.

Comparing changes in correspondent ties of Federal Reserve member and non-member banks provides more evidence that Fed's founding was likely responsible for the reorientation of the interbank network. Congress required all national banks to join the Federal Reserve System but membership was optional for state banks and trust companies. Shown in Table 6, Fed member banks shifted their correspondent links more towards banks in cities with Federal Reserve offices in their Fed district than did non-member banks. For example, between 1910 and 1919, the average percentage of a bank's correspondents located in a Fed city in the bank's district increased by 1.2 percentage points for non-members, 3.5 percentage points for state bank and trust company members, and 5.0 percentage points for national banks.

\footnotetext{
${ }^{15}$ We identified the state banks that belonged to the Federal Reserve System in each year and the districts in which they were located from the Annual Report of the Federal Reserve Board.

${ }^{16}$ Reported in the Appendix, we find similar though weaker patterns when a clearinghouse opened in particular city.
} 


\subsection{The Great Depression}

Next, we investigate the structural changes in the network that occurred during the Great Depression. ${ }^{17}$ In particular, we ask whether the relative increase in correspondent links to Fed office cities in the 1930s resulted from a shift in bank preferences toward establishing connections in nearby Federal Reserve cities, or simply the closures of banks with more dispersed correspondents. We address this question by examining changes in the correspondents of banks that did not close during the 1930s, and then by examining differences in correspondent patterns between surviving and closed banks.

The top panel of Table 7 displays correspondent information for banks that survived from 1929 to 1940 . These data show that surviving banks shifted their correspondent links toward banks in Federal Reserve cities, particularly Fed cities in their district. For example, among all banks that survived the decade, the average percentage of correspondents located in a local Federal Reserve city increased by 3.1 percentage points, from 44.5 percent to 47.6 percent. On average, in 1940, banks that survived the decade had more correspondents, and more located in Fed cities, than in 1929. This reorientation occurred despite the fact that Fed cities generally had as many bank closures as other cities. Fed cities experienced significantly larger increases in eigenvector centrality than did other large cities with similar percentage changes in number of banks, and the correlation between the change in eigenvector centrality and the change in the number of banks between 1929 and 1940 is negative. ${ }^{18}$ Hence, the increase in network focus on

\footnotetext{
${ }^{17}$ Because our data are limited to observations on the network in 1929 and 1940, we are unable to identify separately the effects of the banking panics and other financial distresses on the network from those of the changes in regulation that occurred later in the decade. We discussing the effects of the Great Depression, therefore, we are referring to the totality of events that occurred during the period.

${ }^{18}$ The negative correlation is apparent in Appendix Figure A.1.
} 
Fed cities between 1929 and 1940 was driven at least in part by surviving banks choosing to increase their links to Fed cities.

The bottom panel of Table 7 reports various correspondent measures for banks according to whether they closed during the Depression or survived. ${ }^{19}$ Although survivors and closed banks were somewhat similar in terms of most values, on the eve of the Depression, higher percentages of the correspondents of survivors were located in their district's Fed cities. Among all bank types, on average, 43.9 percent of the correspondents of survivors were located in a local Federal Reserve city, compared with an average of 41.3 percent for banks that closed. The average distance in miles to a correspondent was also substantially shorter for survivors, at 253.4 miles compared with 301.5 miles for banks that closed. These findings are consistent with the idea that access to a Fed office in a bank's district, perhaps only indirectly through a correspondent in that city, conveyed an advantage that reduced a bank's likelihood of closing during the Great Depression. Because data on Federal Reserve lending to specific banks are unavailable, we cannot determine whether that advantage resulted from direct injections of liquidity or perhaps simply that having a correspondent in a Fed city enhanced a bank's reputation with its depositors. Nonetheless, the differences between closed and surviving banks in average numbers (and percentages) of correspondents located in nearby Fed cities are striking.

As suggested by previous work on contagion during the Great Depression, we note an association between a bank's odds of surviving the Depression and the survival rate of its correspondents. Among banks that survived the Depression, the average correspondent closure rate was 24.2 percent, whereas among banks that closed, the average correspondent closure rate

\footnotetext{
${ }^{19}$ We consider a bank closed if it is listed in the Rand McNally Bankers' Directory in 1929 but not in 1940. Therefore, we treat banks that suspended but later reopened during the decade as survivors.
} 
was 31.9 percent. The positive correlation holds separately for national banks as well as for state banks and trust companies regardless of whether they were Fed members. ${ }^{20}$ Lacking the exact dates when banks close, we cannot definitively determine the direction of causality between the closures of banks and their correspondents. However, a bank would be more likely to suffer impaired assets leading to failure when its correspondent closed, than would a correspondent bank when its respondent closed. ${ }^{21}$

\section{Conclusion}

The interconnected nature of financial networks can propagate shocks, increase systemic risk, and magnify economic downturns. Theoretical studies suggest that the vulnerability of interbank networks to systemic risk is related both to the extent of interconnections between members of the network and their relative sizes, as well as to the magnitude of shocks hitting the system. The "core-periphery" structure of the U.S. interbank system during the second half of the nineteenth century and first decades of the twentieth century had a high potential for contagion via formal correspondent connections between banks. The failure of a major correspondent bank could have ripple effects across the entire system, but even the failure of a mid-size correspondent bank in a regional banking center could trigger local contagion.

The Federal Reserve was intended to reduce the banking system's reliance on the interbank network, and especially the concentration of the system's reserves in New York City. Although the share of interbank deposits held by major New York City banks did fall after the

\footnotetext{
${ }^{20}$ Appendix Figure A.2 shows that the positive correlation holds across all values of correspondent closures.

${ }^{21}$ Respondent closures could impose costs on correspondent banks. For example, Mitchener and Richardson (2019) show that correspondent banks reduced their lending when they experienced outflows of respondent deposits. However, while such outflows would force correspondents to either reduce lending or turn to more expensive sources of funds, outflows of respondent deposits are not likely to put a correspondent bank out of business.
} 
Fed was established, previous studies have not examined how the interbank network changed with the introduction of the Fed. Using newly digitized data on the interbank relationships of every U.S. depository institutions in 1900, 1910, 1919, 1929 and 1940, we quantify changes in network concentration and other aspects of network structure over four decades. We show that while New York City remained the network's most important node, nearly all of the other cities that received Federal Reserve Banks or branches gained connections and became more central to the network after the Fed was established. Ironically, by pushing the network toward the regional Fed cities, the System's founders may have inadvertently made the banking system more vulnerable to regional liquidity shocks and to the responsiveness of local Federal Reserve Bank officials to those events. ${ }^{22}$

Comprehensive analysis of network characteristics during the Great Depression reveals that surviving banks responded to the Depression by linking even more to correspondents in cities with Federal Reserve offices, especially New York City. We show that the increased importance of Fed cities to the network during the 1930s was not the result of lower bank closure rates in those cities, a shift in preferences toward large cities in general, or to changes in the composition of the banking system resulting from bank closures. Further, we find that banks with correspondents that failed or otherwise closed were themselves more likely to close during the

\footnotetext{
${ }^{22}$ Friedman and Schwartz (1963) emphasize parochialism and inattention to national concerns among local Federal Reserve officials during the Great Depression, which they argue contributed to the Fed's failure to respond aggressively to banking panics or the sharp decline in economic activity. Richardson and Troost (2009) show that differences in the degree to which officials of different Reserve Banks responded to liquidity shortfalls resulted in significant differences in bank and economic distress between Fed districts. Carlson, Mitchener and Richardson (2011) and Mitchener and Richardson (2019) also show how the responses of the individual Reserve Banks to panics affected local outcomes.
} 
Depression. While testing the effects of these connections alongside a host of other explanatory variables is outside the scope of the present paper, the association supports a growing literature finding evidence that interbank contagion was an important feature of bank distress during the Great Depression. 


\section{References}

Acemoglu, Daron, Asuman Ozdaglar, and Alireza Tahbaz-Salehi. "Systemic risk and stability in financial networks." American Economic Review 105 (2), 2015, pp. 564-608.

Allen, Franklin, and Ana Babus. "Networks in finance." In The network challenge: strategy, profit, and risk in an interlinked world (2009): 367-382.

Allen, Franklin, and Douglas Gale. "Financial contagion." Journal of Political Economy 108 (1), 2000, pp. 1-33.

Allen, Franklin, and Douglas Gale. "Systemic risk and regulation." The risks of financial institutions. University of Chicago Press, 2007. 341-376.

Anderson, Haelim, Charles W. Calomiris, Matthew Jaremski, and Gary Richardson. "Liquidity Risk, Bank Networks, and the Value of Joining the Federal Reserve System." Journal of Money, Credit and Banking 50, 2018, pp. 173-201.

Bernstein, Asaf, Eric Hughson, and Marc D. Weidenmier. "Identifying the Effects of a Lender of Last Resort on Financial Markets: Lessons from the Founding of the Fed." Journal of Financial Economics 98, 2010, pp. 40-53.

Board of Governors of the Federal Reserve System. All Bank Statistics. Washington, D.C.: Board of Governors of the Federal Reserve System, 1959.

Calomiris, Charles W., and Mark Carlson. "Corporate governance and risk management at unprotected banks: National banks in the 1890s." Journal of Financial Economics 119 (3), 2016, pp. 512-532.

Calomiris, Charles W., and Mark Carlson. "Interbank networks in the national banking era: their purpose and their role in the panic of 1893." Journal of Financial Economics 125 (3), 2017, pp. 434-453.

Calomiris, Charles W., and Gary Gorton. "The origins of banking panics: models, facts, and bank regulation." In Financial Markets and Financial Crises, edited by R. Glenn Hubbard. Chicago: University of Chicago Press, 1991, pp. 109-174.

Calomiris, Charles W., Matthew Jaremski, and David C. Wheelock. "Interbank Connections, Contagion and Bank Distress in the Great Depression." Federal Reserve Bank of St. Louis Working Paper no. 2019-001, January 2019.

Carlson, Mark, Kris James Mitchener, and Gary Richardson. "Arresting banking panics: Federal Reserve liquidity provision and the forgotten panic of 1929." Journal of Political Economy 119, 2011, pp. 889-924.

Carlson, Mark and David C. Wheelock. "Did the Founding of the Federal Reserve Affect the Vulnerability of the Interbank System to Contagion Risk?" Journal of Money, Credit and Banking 50 (no. 8), December 2018, pp. 1071-1050.

Carlson, Mark, and David C. Wheelock. "Interbank Markets and Banking Crises: New Evidence on the Establishment and Impact of the Federal Reserve." American Economic Review Papers and Proceedings 106 (no. 5), May 2016, pp. 533-37.

Cohen-Cole, Ethan, Eleonora Patacchini, and Yves Zenou. "Systemic Risk and Network Formation in the Interbank Market." CEPR Discussion Paper, July 8, 2016.

Comptroller of the Currency. Annual Report of the Comptroller of the Currency. Various Years. Washington, DC: Government Printing Office.

Cont, Rama, Amal Moussa, and Edson B. Santos. "Network Structure and Systemic Risk in Banking Systems," in J. Fouque and J. Langsam, eds., Handbook on Systemic Risk. Cambridge: Cambridge University Press, 2013, pp. 327-368. 
Craig, Ben, and Goetz Von Peter. "Interbank tiering and money center banks." Journal of Financial Intermediation 23 (no.3), 2014, pp. 322-347.

Das, Sanjiv R., Kris James Mitchener, and Angela Vossmeyer. "Systemic Risk and the Great Depression.” National Bureau of Economic Research working paper no. 25405, December 2018.

Dasgupta, Amil. "Financial contagion through capital connections: A model of the origin and spread of bank panics." Journal of the European Economic Association 2, 2004 pp. 10491084.

Davison, Lee K. and Carlos D. Ramirez. "Local banking panics of the 1920s: Identification and determinants." Journal of Monetary Economics 66, 2014, pp. 164-177.

Freixas, Xavier, Bruno M. Parigi, and Jean-Charles Rochet. "Systemic risk, interbank relations, and liquidity provision by the central bank." Journal of Money, Credit and Banking, 2000, pp. 611-638.

Friedman, Milton and Anna J. Schwartz. A Monetary History of the United States 1867-1960. Princeton: Princeton University Press, 1963.

Gai, Prasanna, Andrew Haldane, and Sujit Kapadia. "Complexity, concentration and contagion." Journal of Monetary Economics 58 (no. 5), 2011, pp. 453-470.

Gorton, Gary. "Clearinghouses and the origin of central banking in the United States." Journal of Economic History 45, 1985, pp. 277-283.

Gorton, Gary and D. Mullineaux. "The joint production of confidence: endogeneous regulation and $19^{\text {th }}$ century commercial-bank clearinghouses." Journal of Money, Credit, and Banking 19, 1987, pp. 457-468.

Gorton, Gary B. and Ellis W. Tallman. Fighting Financial Crises: Learning from the Past. Chicago: University of Chicago Press, 2018.

Heitfield, Erik, Gary Richardson, and Shirley Wang. "Contagion During the Initial Banking Panic of the Great Depression." NBER Working Paper w23629, 2017.

James, John A. Money and Capital Markets in Postbellum America. Princeton: Princeton University Press, 1978.

James, John A., and David F. Weiman. "From drafts to checks: the evolution of correspondent banking networks and the formation of the modern US payments system, 1850-1914." Journal of Money, Credit and Banking 42 (no. 2-3), 2010, pp. 237-265.

Jaremski, Matthew. "The (Dis)Advantages of Clearinghouses Before the Fed" Forthcoming Journal of Financial Economics, 2019.

Jaremski, Matthew and David C. Wheelock. "Banker preferences, interbank connections, and the enduring structure of the Federal Reserve System." Explorations in Economic History 66, 2017, pp. 21-43.

Miron, Jeffrey A. "Financial Panics, the Seasonality of the Nominal Interest Rate, and the Founding of the Fed." American Economic Review 76, 1986, pp. 125-40.

Mitchener, Kris J., and Gary Richardson. "Network contagion and interbank amplification during the Great Depression." Journal of Political Economy, forthcoming 2019.

Myers, Margaret G. The New York Money Market. Volume 1. New York: Columbia University Press, 1931.

Newman, Mark E. J. "The mathematics of networks." In The New Palgrave Dictionary of Economics 2, 2008, pp. 4059-4064. 
Odell, Kerry A., and David F. Weiman. "Metropolitan development, regional financial centers, and the founding of the Fed in the Lower South." Journal of Economic History 58, 1998, pp. 103-125.

Officer, L. "What was the value of the US consumer bundle then?" MeasuringWorth, 2008 (http://www.measuringworth.org/consumer/).

Paddrik, Mark E. and Anderson, Haelim and Wang, Jessie Jiaxu. "Bank Networks and Systemic Risk: Evidence from the National Banking Acts.” Forthcoming, 2019.

Puhr, Claus, Reinhardt Seliger, and Michael Sigmund. "Contagiousness and vulnerability in the Austrian interbank market." Oesterreichische Nationalbank Financial Stability Report Vol. 24, December 2012.

Redenius, Scott Arnold. "Between reforms: The US banking system in the postbellum period." PhD diss., Yale University, 2002.

Richardson, Gary. "The Check is in the Mail: Correspondent Clearing and the Collapse of the Banking System, 1930 to 1933. Journal of Economic History 67 (3), 2007, pp. 643-71.

Richardson, Gary and William Troost. "Monetary Intervention Mitigated Banking Panics during the Great Depression: Quasi-Experimental Evidence from a Federal Reserve District Border, 1929-1933." Journal of Political Economy 117, 2009, pp. 1031-1073.

Richardson, Gary and Patrick Van Horn. "In the Eye of a Storm: Manhattan's Money Center Banks during the International Financial Crisis of 1931." Explorations in Economic History 68, April 2018, pp. 71-94.

Sprague, O.M.W. History of Crises under the National Banking System. Washington, DC: National Monetary Commission, Senate Document 538, 61st Congress, 2d Session, 1910.

Timberlake, Richard. "The central banking role of clearinghouse associations." Journal of Money, Credit, and Banking 16, 1984, pp. 1-15.

United States National Monetary Commission. Letter from Secretary of the National Monetary Commission, Transmitting, Pursuant to Law, the Report of the Commission January 8, 1912. (https://fraser.stlouisfed.org/title/?id=641)

Watkins, Leonard L. Bankers' Balances: A Study of the Effects of the Federal Reserve System on Banking Relationships. Chicago: A. W. Shaw Company, 1929.

Wicker, Elmus. Banking Panics of the Gilded Age. Cambridge, UK: Cambridge University Press, 2000. 


\section{Appendix: Establishment of Clearinghouses}

Clearinghouses played a substantial role in the nation's payment system and interbank network before the founding of the Federal Reserve. First established in New York City in 1853, clearinghouses were private organizations created by banks to reduce clearing and settlement costs by providing a central location and fixed daily time to clear checks, notes, and drafts within their city. Clearinghouses quickly evolved to also monitor banks, publish information, and provide emergency liquidity during financial panics (Timberlake, 1984; Gorton, 1985; Gorton and Mullineaux, 1987). Much like a central bank, clearinghouses facilitated the clearing of checks, notes, and drafts for their members and, by extension, the respondents of their members, and provided a liquidity backstop should a panic emerge. Jaremski (2019) shows that cities saw large increases in interbank funds after they established a clearinghouse, suggesting that banks preferred to establish connections to banks in cities with a clearinghouse.

Table A2 provides further evidence on the importance of clearinghouses to the interbank network. Here we examine the association between the presence of a clearinghouse and both the number of correspondent connections per bank and the city-level eigenvector centrality score. We include only cities that had at least one bank throughout the sample period to avoid confusing changes due to the establishment of a clearinghouse with changes resulting from adding cities that gained their first bank. The results indicate that banks in cities with a clearinghouse had substantially more correspondent and respondent connections, and more growth over time in the average number of connections, than banks in cities that never established a clearinghouse. For those locations that established a clearinghouse during the sample period, the table suggests that the importance of individual cities (measured, for example, by eigenvector centrality score) increased the most in the decade of the clearinghouse's 
establishment. The evidence thus confirms that cities with bank clearinghouses served as especially important nodes on the interbank network. 
Figure 1: Interbank Holdings of Commercial Banks (1896-1950) Panel A: Real Values (\$1900 Millions)
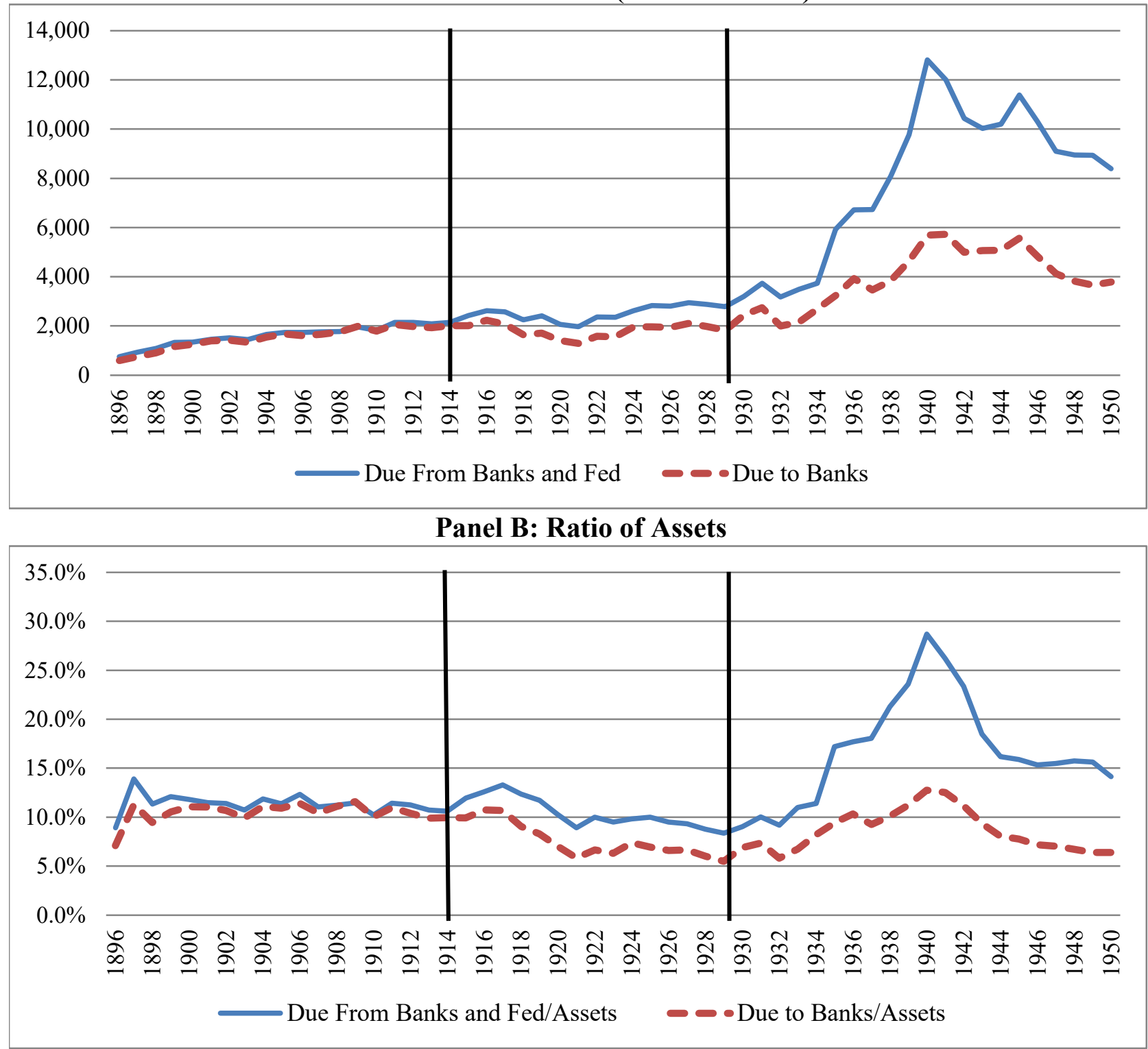

Notes: Figures present the aggregate values of due from banks (i.e. interbank assets) and due to banks (i.e., interbank liabilities). Data come from Federal Reserve Board (1959). Dollar values are deflated to 1900 using Officer (2008). The vertical lines denote the beginning of Fed operations in 1914 and the beginning of the Great Depression in 1929. 
Figure 2: Changes in Eigenvector Centrality (1910-1940)

Panel A: Change 1910-1919

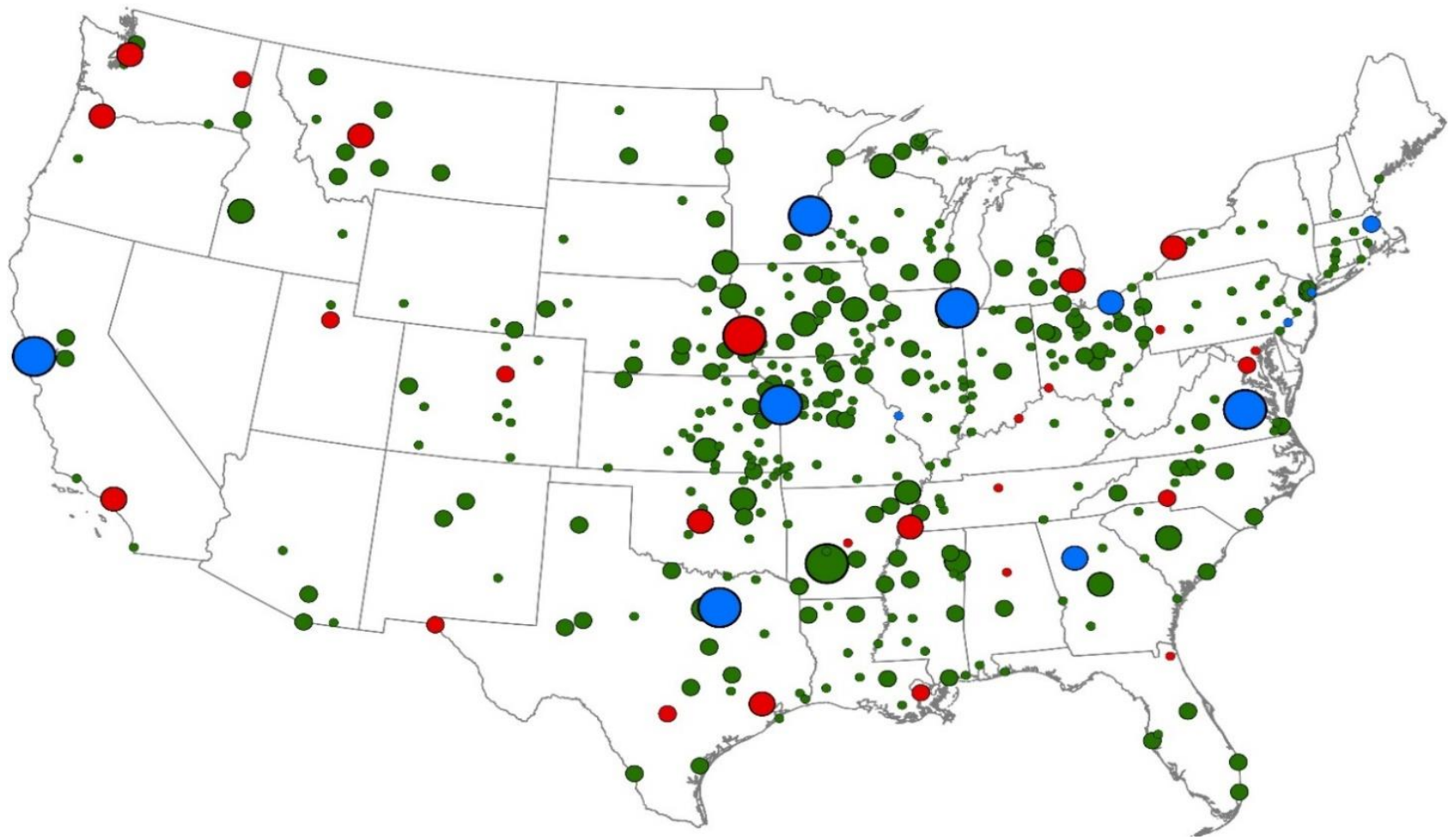

Panel B: Change 1929-1940

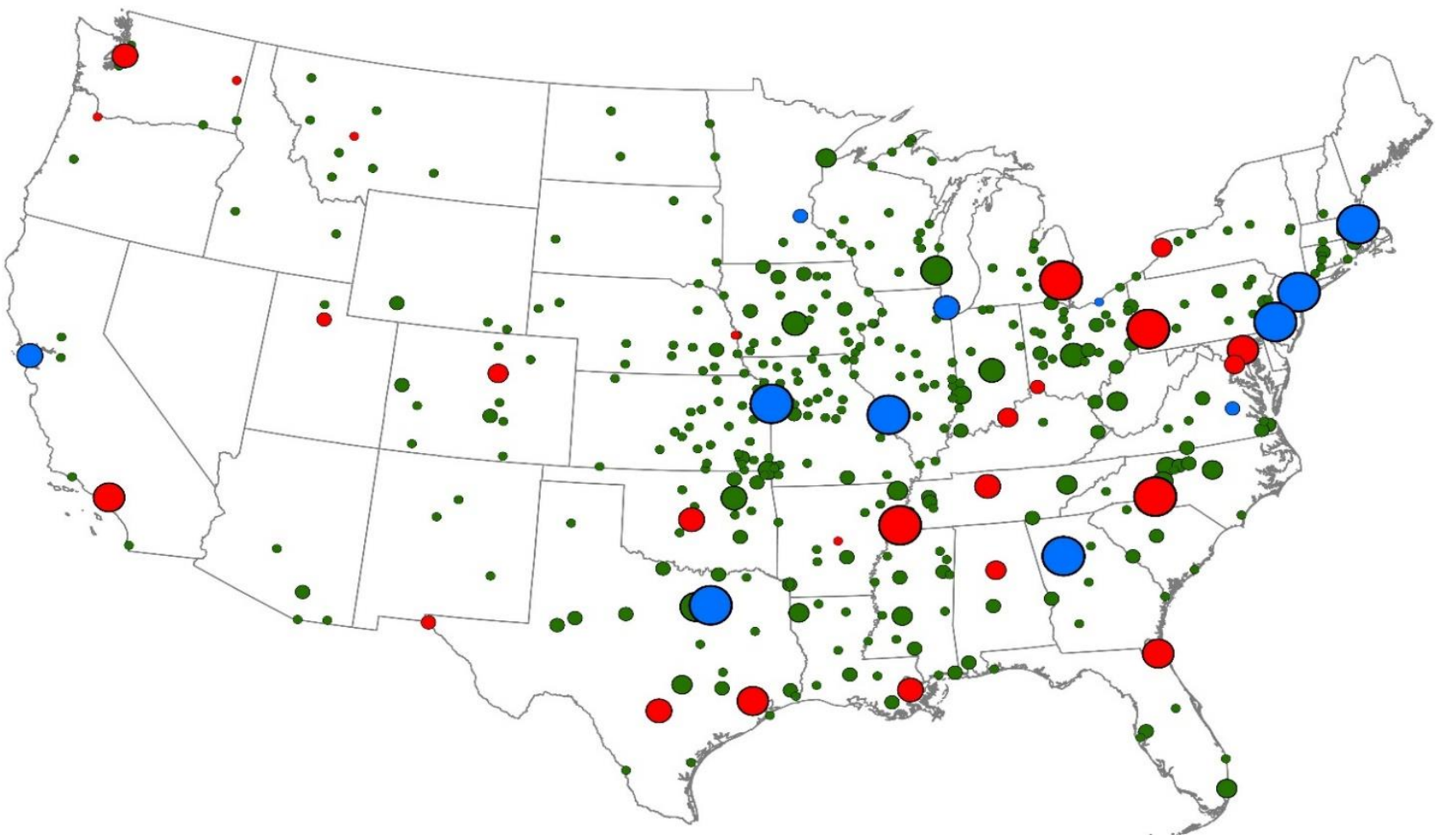

Notes: These figures map out the change in the level of eigenvector centrality for each city across the provided timeperiod. The size of the dot denotes how large the change was, and the color of the dot denotes whether it was a Fed Reserve Bank city (in Blue), a Fed Branch City (in Red), or another city (in Green). We only include cities that both had banks between 1900 and 1940 and achieved an eigenvector centrality measure of at least 0.020 sometime between 1900 and 1940. 


\begin{tabular}{lccccc}
\hline & \multicolumn{5}{c}{ All Banks } \\
\cline { 2 - 6 } Number of Banks & $\mathbf{1 9 0 0}$ & $\mathbf{1 9 1 0}$ & $\mathbf{1 9 1 9}$ & $\mathbf{1 9 2 9}$ & $\mathbf{1 9 4 0}$ \\
Avg. \# of Correspondents & 12,975 & 25,101 & 29,857 & 27,279 & 15,840 \\
\% With 1 Correspondent & 2.336 & 2.191 & 2.840 & 2.882 & 3.185 \\
\% With 2 Correspondents & $18.4 \%$ & $15.0 \%$ & $9.9 \%$ & $12.2 \%$ & $10.2 \%$ \\
\% With 3 Correspondents & $42.3 \%$ & $62.6 \%$ & $33.2 \%$ & $30.0 \%$ & $25.9 \%$ \\
\% With 4 Correspondents & $29.2 \%$ & $13.9 \%$ & $30.2 \%$ & $31.2 \%$ & $32.4 \%$ \\
\% With 5 Correspondents & $7.8 \%$ & $6.6 \%$ & $20.3 \%$ & $19.2 \%$ & $19.8 \%$ \\
\% With 6+ Correspondents & $1.3 \%$ & $1.2 \%$ & $4.4 \%$ & $4.2 \%$ & $5.5 \%$ \\
\% With 0 Respondents & $0.8 \%$ & $0.6 \%$ & $2.0 \%$ & $3.0 \%$ & $5.7 \%$ \\
\% With 1 Respondent & $90.4 \%$ & $90.3 \%$ & $87.1 \%$ & $86.9 \%$ & $87.5 \%$ \\
\% With 2 Respondents & $4.1 \%$ & $4.6 \%$ & $5.8 \%$ & $5.5 \%$ & $5.5 \%$ \\
\% With 3-5 Respondents & $1.3 \%$ & $1.4 \%$ & $2.0 \%$ & $2.1 \%$ & $1.7 \%$ \\
\% With 5-15 Respondents & $1.4 \%$ & $1.3 \%$ & $1.9 \%$ & $2.2 \%$ & $2.1 \%$ \\
\% With 16-50 Respondents & $1.1 \%$ & $1.0 \%$ & $1.4 \%$ & $1.5 \%$ & $1.3 \%$ \\
\% With 51-150 Respondents & $1.0 \%$ & $0.7 \%$ & $0.9 \%$ & $0.9 \%$ & $0.9 \%$ \\
\% With 150+ Respondents & $0.5 \%$ & $0.3 \%$ & $0.5 \%$ & $0.5 \%$ & $0.6 \%$ \\
\hline
\end{tabular}

Notes: Table presents number of banks, average number of correspondents per bank, and the percentages of banks with various numbers of correspondents and respondents in each year. 
Table 2: Top 10 Correspondent Banks By Year

\begin{tabular}{|c|c|c|c|c|c|c|c|}
\hline \multicolumn{4}{|l|}{1900} & \multicolumn{4}{|c|}{1910} \\
\hline Bank & Location & \# of Resp. & $\%$ of Banks & Bank & Location & \# of Resp. & $\%$ of Banks \\
\hline Hanover National Bank & New York & 1,465 & $14.71 \%$ & Hanover National Bank & New York & 3,374 & $14.82 \%$ \\
\hline Chase National Bank & New York & 1,204 & $12.09 \%$ & Continental and Commercial National Bank & Chicago & 3,053 & $13.41 \%$ \\
\hline First National Bank & Chicago & 994 & $9.98 \%$ & Chase National Bank & New York & 2,489 & $10.93 \%$ \\
\hline National Park Bank & New York & 690 & $6.93 \%$ & National Park Bank & New York & 2,038 & $8.95 \%$ \\
\hline Western National Bank & New York & 595 & $5.98 \%$ & National Bank of Commerce & New York & 1,424 & $6.25 \%$ \\
\hline National Bank of Commerce & Kansas City & 523 & $5.25 \%$ & First National Bank & Chicago & 1,403 & $6.16 \%$ \\
\hline Importers and Traders National Bank & New York & 440 & $4.42 \%$ & National City Bank & New York & 1,338 & $5.88 \%$ \\
\hline Continental National Bank & Chicago & 434 & $4.36 \%$ & National Bank of Commerce & St Louis & 1,192 & $5.23 \%$ \\
\hline Chemical National Bank & New York & 393 & $3.95 \%$ & Seaboard National Bank & New York & 787 & $3.46 \%$ \\
\hline National City Bank & New York & 365 & $3.67 \%$ & Corn Exchange National Bank (2) & Chicago & 674 & $2.96 \%$ \\
\hline \multirow{2}{*}{\multicolumn{4}{|c|}{$\begin{array}{c}\% \text { of Banks Connected To At Least One Of The Top } 10 \text { Correspondents } \\
1919\end{array}$}} & \multicolumn{3}{|c|}{$\%$ of Banks Connected To At Least One Of The Top 10 Correspondents } & $59.93 \%$ \\
\hline & & & & \multicolumn{4}{|c|}{1929} \\
\hline Bank & Location & \# of Resp. & $\%$ of Banks & Bank & Location & \# of Resp. & $\%$ of Banks \\
\hline Continental and Commercial National Bank & Chicago & 3,659 & $13.07 \%$ & Continental Illinois Bank and Trust Co & Chicago & 4,785 & $18.34 \%$ \\
\hline Hanover National Bank & New York & 3,620 & $12.93 \%$ & Chase National Bank & New York & 3,181 & $12.19 \%$ \\
\hline Chase National Bank & New York & 2,530 & $9.04 \%$ & Hanover National Bank & New York & 2,868 & $10.99 \%$ \\
\hline National Park Bank & New York & 1,942 & $6.94 \%$ & National City Bank & New York & 1,887 & $7.23 \%$ \\
\hline National City Bank & New York & 1,941 & $6.94 \%$ & First National Bank of Chicago & Chicago & 1,675 & $6.42 \%$ \\
\hline First National Bank & Chicago & 1,749 & $6.25 \%$ & National Park Bank & New York & 1,565 & $6.00 \%$ \\
\hline National Bank of Commerce & New York & 1,563 & $5.58 \%$ & National Bank of Commerce & New York & 1,301 & $4.99 \%$ \\
\hline First and Security National Bank & Minneapolis & 1,469 & $5.25 \%$ & First National Bank & Minneapolis & 1,206 & $4.62 \%$ \\
\hline Mechanics and Metals National Bank & New York & 1,172 & $4.19 \%$ & Irving Trust Co & New York & 1,194 & $4.58 \%$ \\
\hline National Bank of Commerce & St Louis & 1,058 & $3.78 \%$ & Philadelphia National Bank & Philadelphia & 1,193 & $4.57 \%$ \\
\hline \multicolumn{3}{|c|}{ \% of Banks Connected To At Least One Of The Top 10 Correspondents } & $56.64 \%$ & \multicolumn{3}{|c|}{$\%$ of Banks Connected To At Least One Of The Top 10 Correspondents } & $53.06 \%$ \\
\hline \multicolumn{4}{|c|}{$\begin{aligned} 1940 \\
\end{aligned}$} & & & & \\
\hline Bank & Location & \# of Resp. & $\%$ of Banks & & & & \\
\hline Chase National Bank & New York & 3,346 & $21.36 \%$ & & & & \\
\hline Continental Illinois National Bank and Trust Co & Chicago & 2,375 & $15.16 \%$ & & & & \\
\hline Central Hanover Bank and Trust Co & New York & 1,634 & $10.43 \%$ & & & & \\
\hline Manufacturers Trust Co & New York & 1,378 & $8.80 \%$ & & & & \\
\hline National City Bank & New York & 1,325 & $8.46 \%$ & & & & \\
\hline Guaranty Trust Co & New York & 1,055 & $6.73 \%$ & & & & \\
\hline Commerce Trust Co & Kansas City & 916 & $5.85 \%$ & & & & \\
\hline Philadelphia National Bank & Philadelphia & 864 & $5.51 \%$ & & & & \\
\hline Chemical Bank and Trust Co & New York & 790 & $5.04 \%$ & & & & \\
\hline First National Bank and Trust Co & Minneapolis & 740 & $4.72 \%$ & & & & \\
\hline \multicolumn{3}{|c|}{$\%$ of Banks Connected To At Least One Of The Top 10 Correspondents } & $56.77 \%$ & & & & \\
\hline
\end{tabular}

connected to at least one of the top 10 correspondents. Some banks were connected to more than one of the top 10 correspondent banks and, thus, it is not a simple sum of the individual percentages. 
Table 3: Top 10 Correspondent Cities By Year

\begin{tabular}{|c|c|c|c|c|c|c|c|}
\hline \multicolumn{4}{|c|}{1900} & \multicolumn{4}{|c|}{1910} \\
\hline State & Location & \# of Resp. & \# of Resp. & State & Location & \# of Resp. & \# of Resp. \\
\hline NY & New York & 8,488 & $85.26 \%$ & NY & New York & 15,690 & $68.90 \%$ \\
\hline IL & Chicago & 3,449 & $34.64 \%$ & IL & Chicago & 7,269 & $31.92 \%$ \\
\hline MO & St Louis & 1,295 & $13.01 \%$ & MO & St Louis & 2,996 & $13.16 \%$ \\
\hline $\mathrm{PA}$ & Philadelphia & 1,181 & $11.86 \%$ & MO & Kansas City & 2,298 & $10.09 \%$ \\
\hline MA & Boston & 1,074 & $10.79 \%$ & $\mathrm{MN}$ & Minneapolis & 2,148 & $9.43 \%$ \\
\hline MO & Kansas City & 1,045 & $10.50 \%$ & PA & Philadelphia & 2,061 & $9.05 \%$ \\
\hline $\mathrm{MN}$ & Minneapolis & 667 & $6.70 \%$ & MA & Boston & 1,055 & $4.63 \%$ \\
\hline $\mathrm{OH}$ & Cincinnati & 577 & $5.80 \%$ & $\mathrm{OH}$ & Cincinnati & 890 & $3.91 \%$ \\
\hline $\mathrm{NE}$ & Omaha & 488 & $4.90 \%$ & NE & Omaha & 862 & $3.79 \%$ \\
\hline KY & Louisville & 385 & $3.87 \%$ & $\mathrm{PA}$ & Pittsburgh & 860 & $3.78 \%$ \\
\hline \multicolumn{3}{|c|}{$\%$ of Banks Connected to At Least One of Top 10 Cities } & $95.54 \%$ & \multicolumn{3}{|c|}{$\%$ of Banks Connected to At Least One of Top 10 Cities } & $91.95 \%$ \\
\hline \multicolumn{4}{|c|}{$\begin{array}{ll} & 1919 \\
\end{array}$} & \multicolumn{4}{|c|}{$\begin{array}{lc}1929 \\
\end{array}$} \\
\hline State & Location & \# of Resp. & \# of Resp. & State & Location & \# of Resp. & \# of Resp. \\
\hline NY & New York & 17,829 & $63.70 \%$ & NY & New York & 16,437 & $63.00 \%$ \\
\hline IL & Chicago & 9,915 & $35.43 \%$ & IL & Chicago & 9,229 & $35.38 \%$ \\
\hline $\mathrm{MN}$ & Minneapolis & 5,008 & $17.89 \%$ & $\mathrm{MN}$ & Minneapolis & 3,504 & $13.43 \%$ \\
\hline MO & Kansas City & 4,493 & $16.05 \%$ & MO & Kansas City & 3,149 & $12.07 \%$ \\
\hline MO & St Louis & 3,491 & $12.47 \%$ & MO & St Louis & 3,138 & $12.03 \%$ \\
\hline PA & Philadelphia & 2,564 & $9.16 \%$ & PA & Philadelphia & 2,595 & $9.95 \%$ \\
\hline $\mathrm{NE}$ & Omaha & 1,875 & $6.70 \%$ & PA & Pittsburgh & 1,611 & $6.18 \%$ \\
\hline MA & Boston & 1,380 & $4.93 \%$ & MA & Boston & 1,608 & $6.16 \%$ \\
\hline $\mathrm{CA}$ & San Francisco & 1,342 & $4.79 \%$ & $\mathrm{NE}$ & Omaha & 1,457 & $5.58 \%$ \\
\hline PA & Pittsburgh & 1,199 & $4.28 \%$ & WI & Milwaukee & 1,063 & $4.07 \%$ \\
\hline \multicolumn{3}{|c|}{$\%$ of Banks Connected to At Least One of Top 10 Cities } & $88.94 \%$ & \multicolumn{3}{|c|}{ \% of Banks Connected to At Least One of Top 10 Cities } & $83.84 \%$ \\
\hline \multicolumn{4}{|c|}{$\begin{aligned} 1940 \\
\end{aligned}$} & & & & \\
\hline State & Location & \# of Resp. & \# of Resp. & & & & \\
\hline NY & New York & 11,719 & $74.80 \%$ & & & & \\
\hline IL & Chicago & 3,845 & $24.54 \%$ & & & & \\
\hline MO & Kansas City & 2,276 & $14.53 \%$ & & & & \\
\hline $\mathrm{MN}$ & Minneapolis & 2,129 & $13.59 \%$ & & & & \\
\hline MO & St Louis & 1,939 & $12.38 \%$ & & & & \\
\hline PA & Philadelphia & 1,762 & $11.25 \%$ & & & & \\
\hline MA & Boston & 1,588 & $10.14 \%$ & & & & \\
\hline PA & Pittsburgh & 1,185 & $7.56 \%$ & & & & \\
\hline $\mathrm{NE}$ & Omaha & 810 & $5.17 \%$ & & & & \\
\hline WI & Milwaukee & 801 & $5.11 \%$ & & & & \\
\hline \multicolumn{3}{|c|}{$\%$ of Banks Connected to At Least One of Top 10 Cities } & $81.75 \%$ & & & & \\
\hline
\end{tabular}

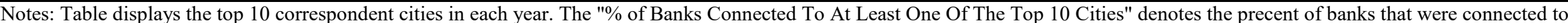
at least one of the top 10 cities. Some banks were connected to more than one of the top 10 cities and, thus, it is not a simple sum of the individual percentages. 
Table 4: Change in City-Level Centrality Statistics (1900-1940)

\begin{tabular}{|c|c|c|c|c|c|}
\hline & \multicolumn{5}{|c|}{ Degree Centrality } \\
\hline & 1900 & $\Delta 1900-10$ & $\Delta 1910-19$ & $\Delta 1919-29$ & $\Delta 1929-40$ \\
\hline Mean & $0.09 \%$ & $-0.05 \%$ & $0.00 \%$ & $0.00 \%$ & $0.01 \%$ \\
\hline New York & $75.49 \%$ & $-12.86 \%$ & $-7.61 \%$ & $-7.38 \%$ & $0.58 \%$ \\
\hline Chicago & $32.44 \%$ & $-1.82 \%$ & $0.07 \%$ & $-0.51 \%$ & $-4.11 \%$ \\
\hline St Louis & $13.93 \%$ & $-0.24 \%$ & $-1.92 \%$ & $-1.63 \%$ & $-0.86 \%$ \\
\hline Boston & $7.36 \%$ & $-4.09 \%$ & $-0.01 \%$ & $0.38 \%$ & $1.15 \%$ \\
\hline Philadelphia & $9.25 \%$ & $-1.87 \%$ & $-0.43 \%$ & $0.24 \%$ & $0.77 \%$ \\
\hline Cleveland & $2.64 \%$ & $-0.73 \%$ & $0.51 \%$ & $0.50 \%$ & $-0.35 \%$ \\
\hline Richmond & $1.20 \%$ & $0.35 \%$ & $1.47 \%$ & $-0.18 \%$ & $-0.31 \%$ \\
\hline Atlanta & $1.36 \%$ & $0.20 \%$ & $0.59 \%$ & $0.16 \%$ & $0.98 \%$ \\
\hline Minneapolis & $12.28 \%$ & $-1.39 \%$ & $2.03 \%$ & $-2.31 \%$ & $0.58 \%$ \\
\hline Kansas City & $6.89 \%$ & $2.42 \%$ & $3.41 \%$ & $-2.19 \%$ & $-1.12 \%$ \\
\hline Dallas & $0.61 \%$ & $1.21 \%$ & $1.22 \%$ & $0.26 \%$ & $1.21 \%$ \\
\hline San Francisco & $4.09 \%$ & $-1.55 \%$ & $1.00 \%$ & $-0.36 \%$ & $-0.13 \%$ \\
\hline All Fed Branches & $1.45 \%$ & $-0.08 \%$ & $0.28 \%$ & $0.13 \%$ & $0.23 \%$ \\
\hline \multirow[t]{3}{*}{ Top 100 Non-Fed Cities } & $0.35 \%$ & $-0.05 \%$ & $0.09 \%$ & $0.03 \%$ & $0.04 \%$ \\
\hline & \multicolumn{5}{|c|}{$\begin{array}{l}\text { Eigenvector Centrality } \\
\end{array}$} \\
\hline & 1900 & $\Delta 1900-10$ & $\Delta 1910-19$ & $\Delta 1919-29$ & $\Delta 1929-40$ \\
\hline Mean & $1.79 \%$ & $-1.01 \%$ & $-0.15 \%$ & $0.00 \%$ & $0.27 \%$ \\
\hline New York & $124.53 \%$ & $-36.65 \%$ & $-10.22 \%$ & $1.38 \%$ & $17.82 \%$ \\
\hline Chicago & $56.81 \%$ & $-17.52 \%$ & $1.75 \%$ & $5.93 \%$ & $2.02 \%$ \\
\hline St Louis & $24.79 \%$ & $-8.56 \%$ & $-2.05 \%$ & $-0.22 \%$ & $3.44 \%$ \\
\hline Boston & $12.99 \%$ & $-7.44 \%$ & $0.33 \%$ & $1.60 \%$ & $5.09 \%$ \\
\hline Philadelphia & $17.45 \%$ & $-6.35 \%$ & $-0.40 \%$ & $2.08 \%$ & $6.76 \%$ \\
\hline Cleveland & $7.13 \%$ & $-3.06 \%$ & $0.60 \%$ & $2.53 \%$ & $0.71 \%$ \\
\hline Richmond & $4.34 \%$ & $-1.19 \%$ & $1.36 \%$ & $0.45 \%$ & $1.02 \%$ \\
\hline Atlanta & $4.74 \%$ & $-1.29 \%$ & $0.58 \%$ & $1.15 \%$ & $3.36 \%$ \\
\hline Minneapolis & $20.90 \%$ & $-8.73 \%$ & $1.37 \%$ & $-1.52 \%$ & $4.85 \%$ \\
\hline Kansas City & $13.42 \%$ & $-1.84 \%$ & $1.29 \%$ & $-1.04 \%$ & $1.09 \%$ \\
\hline Dallas & $3.90 \%$ & $-0.13 \%$ & $1.14 \%$ & $0.73 \%$ & $3.23 \%$ \\
\hline San Francisco & $9.55 \%$ & $-4.34 \%$ & $1.71 \%$ & $1.26 \%$ & $2.28 \%$ \\
\hline All Fed Branches & $5.16 \%$ & $-2.11 \%$ & $0.24 \%$ & $0.73 \%$ & $2.02 \%$ \\
\hline \multirow[t]{3}{*}{ Top 100 Non-Fed Cities } & $3.02 \%$ & $-1.36 \%$ & $-0.07 \%$ & $0.35 \%$ & $0.75 \%$ \\
\hline & \multicolumn{5}{|c|}{ Betweenness Centrality } \\
\hline & 1900 & $\Delta 1900-10$ & $\Delta 1910-19$ & $\Delta 1919-29$ & $\Delta 1929-40$ \\
\hline Mean & $0.02 \%$ & $-0.01 \%$ & $0.00 \%$ & $0.00 \%$ & $0.00 \%$ \\
\hline New York & $72.31 \%$ & $-7.98 \%$ & $-7.36 \%$ & $-6.77 \%$ & $0.15 \%$ \\
\hline Chicago & $19.18 \%$ & $5.20 \%$ & $0.76 \%$ & $2.41 \%$ & $-4.42 \%$ \\
\hline St Louis & $6.93 \%$ & $3.58 \%$ & $-1.16 \%$ & $-0.34 \%$ & $-1.12 \%$ \\
\hline Boston & $5.07 \%$ & $-2.78 \%$ & $-0.16 \%$ & $0.74 \%$ & $0.15 \%$ \\
\hline Philadelphia & $3.72 \%$ & $0.10 \%$ & $-0.21 \%$ & $1.03 \%$ & $-0.14 \%$ \\
\hline Cleveland & $0.36 \%$ & $-0.01 \%$ & $0.15 \%$ & $0.85 \%$ & $-0.25 \%$ \\
\hline Richmond & $0.12 \%$ & $0.47 \%$ & $0.59 \%$ & $0.37 \%$ & $-0.24 \%$ \\
\hline Atlanta & $0.20 \%$ & $0.12 \%$ & $0.05 \%$ & $0.42 \%$ & $0.85 \%$ \\
\hline Minneapolis & $5.00 \%$ & $2.37 \%$ & $2.11 \%$ & $-0.79 \%$ & $1.36 \%$ \\
\hline Kansas City & $2.18 \%$ & $3.11 \%$ & $3.47 \%$ & $-0.20 \%$ & $-0.33 \%$ \\
\hline Dallas & $0.04 \%$ & $0.52 \%$ & $0.47 \%$ & $0.67 \%$ & $1.00 \%$ \\
\hline San Francisco & $1.53 \%$ & $-0.67 \%$ & $0.10 \%$ & $0.16 \%$ & $0.52 \%$ \\
\hline All Fed Branches & $0.35 \%$ & $0.21 \%$ & $0.04 \%$ & $0.28 \%$ & $0.19 \%$ \\
\hline Top 100 Non-Fed Cities & $0.07 \%$ & $0.02 \%$ & $0.02 \%$ & $0.03 \%$ & $0.03 \%$ \\
\hline
\end{tabular}

Notes: Table presents centrality scores for 1900 and changes for the indicated periods. Bank-level data are aggregated to the city-level before calculating the statistics. Intra-city connections are excluded in this calculation. Degree centrality is defined as the percentage of other cities that a city is connected to in a given year. Eigenvector centrality is normalized to total 100 for all cities in a year and is reported in percentage point terms. Betweenness centrality is defined as the percentage of paths between all citypairs that includes the given city. "Top 100 Non-Fed Cities" is based on city population in 1910. Changes are calculated as the simple change from one year to the next, expressed in percentages. 


\begin{tabular}{|c|c|c|c|c|c|}
\hline & \multicolumn{5}{|c|}{ All Banks } \\
\hline & 1900 & 1910 & 1919 & 1929 & 1940 \\
\hline Avg. \% National Bank Correspondents & $89.8 \%$ & $90.7 \%$ & $86.7 \%$ & $72.2 \%$ & $72.0 \%$ \\
\hline Avg. \% State Bank Correspondents & $6.9 \%$ & $4.5 \%$ & $7.1 \%$ & $5.1 \%$ & $3.5 \%$ \\
\hline Avg. \% Fed Member State Banks Correspondents & - & - & $3.2 \%$ & $2.0 \%$ & $2.0 \%$ \\
\hline Avg. \% Non-Fed Member State Banks Correspondents & - & - & $3.9 \%$ & $3.1 \%$ & $1.5 \%$ \\
\hline Avg. \% Trust Co Correspondents & $3.3 \%$ & $4.8 \%$ & $6.3 \%$ & $22.7 \%$ & $24.5 \%$ \\
\hline Avg. \% Fed Member Trust Co Correspondents & - & - & $4.5 \%$ & $17.5 \%$ & $23.2 \%$ \\
\hline Avg. \% Non-Fed Member Trust Co Correspondents & - & - & $1.8 \%$ & $5.2 \%$ & $1.4 \%$ \\
\hline Avg. \% Any Fed Bank or Branch City Correspondents & $85.9 \%$ & $83.4 \%$ & $75.3 \%$ & $74.8 \%$ & $78.3 \%$ \\
\hline Avg. \% New York Correspondents & $33.5 \%$ & $30.5 \%$ & $21.8 \%$ & $21.7 \%$ & $23.4 \%$ \\
\hline Avg. \% Chicago Correspondents & $16.3 \%$ & $15.3 \%$ & $12.9 \%$ & $12.4 \%$ & $10.3 \%$ \\
\hline Avg. \% St Louis Correspondents & $5.1 \%$ & $5.9 \%$ & $4.4 \%$ & $4.1 \%$ & $3.9 \%$ \\
\hline Avg. \% Non-CRC Fed Bank or Branch City Correspondents & $31.0 \%$ & $31.8 \%$ & $36.1 \%$ & $36.6 \%$ & $40.7 \%$ \\
\hline Avg. \% Correspondents in District's Fed Cities & $40.1 \%$ & $38.3 \%$ & $40.3 \%$ & $42.6 \%$ & $46.0 \%$ \\
\hline Avg. Distance to Correspondents (in Miles) & 379 & 404 & 316 & 277 & 233 \\
\hline
\end{tabular}

Notes: Tables provides summary statistics for each variable in each year. "Avg. $\% \mathrm{X}$ " denotes the percentage of the average bank's correspondents that have the characteristic "X". "State Bank Correspondents" denotes correspondent banks that have state charters; "Fed Member State Banks Correspondents" are state-chartered Federal Reserve members; "NonFed Member State Banks Correspondents" are state-chartered non-Fed members. "Trust Co Corrrespondents" denotes correspondent trust companies (all of which are state chartered); "Fed Member Trust Co Correspondents" are Fed members; "Non-Fed Member Trust Co Correspondents" are non-Fed members. "National Bank Correspondents" denotes correspondent banks that are national banks. "Any Fed Bank or Branch City Correspondents" denotes correspondents that were located in any city with a Federal Reserve Bank or branch. "New York Correspondents" denotes correspondents located in New York City. "Chicago Correspondents" denotes correspondents located in Chicago. "St Louis Correspondents" denotes correspondents located in St Louis. "Non-CRC Fed Bank or Branch City Correspondents" denotes correspondents located any city with a Federal Reserve Bank or branch except New York City, Chicago, or St Louis. "Correspondents in District's Fed Cities" denotes correspondents that were located in a city with a Federal Reserve Bank or branch in the bank's district. "Avg. Distance to Correspondents (in Miles)" denotes the average distance in miles between a bank and all of its correspondents. 
Table 6: Change in Correspondent Distributions Among Surviving Banks (1910-1919)

Banks that Survived 1910-19

\# of Banks

Avg. \# of Respondents

Avg. \% Any Fed Bank or Branch City Correspondents

Avg. \% New York Correspondents

Avg. \% Chicago Correspondents

Avg. \% St Louis Correspondents

Avg. \% Non-CRC Fed City Correspondents

Avg. \% Correspondents in District's Fed Cities

Avg. Distance to Correspondents (in Miles)
\# of Banks

Avg. \% Any Fed Bank or Branch City Correspondents

Avg. \% Chicago Correspondents

Avg. \% Non-CRC Fed City Correspondents
Avg. \# of Respondents

Avg. \% New York Correspondents

Avg. \% St Louis Correspondents

Avg. \% Correspondents in District's Fed Cities

National Banks

\begin{tabular}{lc}
$\begin{array}{l}\text { Non-Fed State Banks } \\
\text { and Trust Companies }\end{array}$ & $\begin{array}{c}\text { Fed Member State Banks } \\
\text { and Trust Companies }\end{array}$ \\
\hline
\end{tabular}

$\begin{array}{lll}1910 & 1919 & \text { Diff. }\end{array}$

$12,078 \quad 12,078$

$0.09 \quad 0.25 \quad 0.15$

$78.4 \% \quad 71.7 \% \quad-6.7 \%$

$26.7 \% \quad 19.5 \% \quad-7.2 \%$

$14.1 \% \quad 11.9 \% \quad-2.2 \%$

$6.0 \% \quad 4.9 \% \quad-1.1 \%$

$31.5 \% \quad 35.5 \% \quad 3.9 \%$

$39.4 \% \quad 40.6 \% \quad 1.2 \%$

$367.4 \quad 294.6 \quad-72.8$

-

\begin{tabular}{lr}
\hline Non-Fed State Banks & Fed Member State Banks \\
and Trust Companies & and Trust Companies \\
\hline
\end{tabular}

\begin{tabular}{|c|c|c|c|c|c|c|c|c|c|c|c|}
\hline 1910 & 1929 & Diff. & 1910 & 1929 & Diff. & 1910 & 1929 & Diff. & 1910 & 1929 & Diff. \\
\hline 6,947 & 6,947 & - & 646 & 646 & - & 4,523 & 4,523 & - & 12,116 & 12,116 & - \\
\hline 0.08 & 0.31 & 0.23 & 1.79 & 8.65 & 6.86 & 5.20 & 7.84 & 2.64 & 2.08 & 3.57 & 1.49 \\
\hline $77.8 \%$ & $69.0 \%$ & $-8.8 \%$ & $89.5 \%$ & $86.5 \%$ & $-3.0 \%$ & $92.0 \%$ & $84.7 \%$ & $-7.4 \%$ & $84.5 \%$ & $76.3 \%$ & $-8.2 \%$ \\
\hline $26.6 \%$ & $17.3 \%$ & $-9.4 \%$ & $39.7 \%$ & $30.5 \%$ & $-9.2 \%$ & $37.2 \%$ & $27.8 \%$ & $-9.4 \%$ & $31.8 \%$ & $22.3 \%$ & $-9.6 \%$ \\
\hline $14.1 \%$ & $11.1 \%$ & $-2.9 \%$ & $16.2 \%$ & $13.7 \%$ & $-2.5 \%$ & $14.8 \%$ & $12.0 \%$ & $-2.8 \%$ & $14.5 \%$ & $11.7 \%$ & $-2.8 \%$ \\
\hline $6.5 \%$ & $5.4 \%$ & $-1.1 \%$ & $4.0 \%$ & $3.9 \%$ & $-0.1 \%$ & $5.6 \%$ & $3.5 \%$ & $-2.1 \%$ & $6.0 \%$ & $4.5 \%$ & $-1.4 \%$ \\
\hline $30.6 \%$ & $35.2 \%$ & $4.6 \%$ & $29.7 \%$ & $38.4 \%$ & $8.8 \%$ & $34.4 \%$ & $41.3 \%$ & $6.9 \%$ & $32.2 \%$ & $37.8 \%$ & $5.6 \%$ \\
\hline $39.8 \%$ & $42.2 \%$ & $2.4 \%$ & $38.1 \%$ & $43.7 \%$ & $5.6 \%$ & $37.1 \%$ & $43.4 \%$ & $6.3 \%$ & $38.7 \%$ & $42.7 \%$ & $4.0 \%$ \\
\hline 342.7 & 236.0 & -106.7 & 444.4 & 335.1 & -109.4 & 445.97 & 315.83 & -130.1 & 386.67 & 271.01 & -115.7 \\
\hline
\end{tabular}

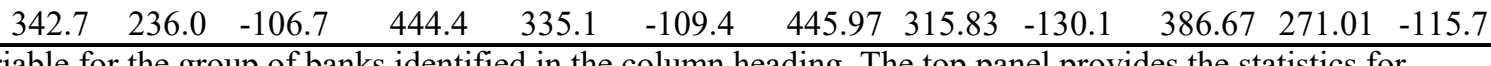

Notes: Tables provides the summary statistics for each variable for the group of banks identified in the column heading. The top panel provides the statistics for

banks that survived from 1910 through 1919, whereas the bottom panel provides the statistics for banks that survived from 1910 through 1929 . Fed membership of state bank and trust companies is denoted as of 1919. "Avg. \# of Respondents" denotes the average number of banks that claim a bank as a correspondent. See notes to Table 5 for other definitions. 
Table 7: Correspondent Distributions of Closed and Surviving Banks (1929-1940)

\begin{tabular}{|c|c|c|c|c|c|c|c|c|c|c|c|c|}
\hline & \multicolumn{12}{|c|}{ Banks that Survived 1929-40 } \\
\hline & \multicolumn{3}{|c|}{$\begin{array}{l}\text { Non-Fed State Banks } \\
\text { and Trust Companies }\end{array}$} & \multicolumn{3}{|c|}{$\begin{array}{c}\text { Fed Member State Banks } \\
\text { and Trust Companies }\end{array}$} & \multicolumn{3}{|c|}{ National Banks } & \multicolumn{3}{|c|}{ All Banks } \\
\hline & 1929 & 1940 & Diff. & 1929 & 1940 & Diff. & 1929 & 1940 & Diff. & 1929 & 1940 & Diff. \\
\hline \# of Banks & 7,372 & 7,372 & - & 570 & 570 & - & 4,396 & 4,396 & - & 12,338 & 12,338 & - \\
\hline Avg. \% Any Fed Bank or Branch City Correspondents & $69.9 \%$ & $72.8 \%$ & $3.0 \%$ & $86.4 \%$ & $88.6 \%$ & $2.2 \%$ & $85.7 \%$ & $86.4 \%$ & $0.7 \%$ & $76.8 \%$ & $79.0 \%$ & $2.1 \%$ \\
\hline Avg. \% New York Correspondents & $18.6 \%$ & $18.3 \%$ & $-0.3 \%$ & $32.5 \%$ & $36.3 \%$ & $3.8 \%$ & $29.0 \%$ & $30.0 \%$ & $1.1 \%$ & $23.3 \%$ & $23.9 \%$ & $0.5 \%$ \\
\hline Avg. \% Chicago Correspondents & $11.0 \%$ & $10.5 \%$ & $-0.6 \%$ & $11.8 \%$ & $11.1 \%$ & $-0.7 \%$ & $10.1 \%$ & $9.0 \%$ & $-1.0 \%$ & $10.7 \%$ & $9.9 \%$ & $-0.8 \%$ \\
\hline Avg. \% St Louis Correspondents & $4.2 \%$ & $4.3 \%$ & $0.2 \%$ & $3.0 \%$ & $3.4 \%$ & $0.4 \%$ & $3.7 \%$ & $3.5 \%$ & $-0.3 \%$ & $3.9 \%$ & $3.9 \%$ & $0.0 \%$ \\
\hline Avg. \% Non-CRC Fed City Correspondents & $36.1 \%$ & $39.7 \%$ & $3.6 \%$ & $39.0 \%$ & $37.8 \%$ & $-1.2 \%$ & $42.9 \%$ & $43.9 \%$ & $0.9 \%$ & $38.9 \%$ & $41.2 \%$ & $2.3 \%$ \\
\hline Avg. \% Correspondents in District's Fed Cities & $43.7 \%$ & $47.5 \%$ & $3.8 \%$ & $45.8 \%$ & $48.7 \%$ & $2.9 \%$ & $45.8 \%$ & $47.7 \%$ & $2.0 \%$ & $44.5 \%$ & $47.6 \%$ & $3.1 \%$ \\
\hline \multirow[t]{4}{*}{ Avg. Distance to Correspondents (in Miles) } & 221.1 & 200.3 & -20.7 & 293.4 & 277.0 & -16.4 & 302.6 & 276.4 & -26.1 & 253.4 & 230.9 & -22.5 \\
\hline & \multicolumn{12}{|c|}{ Comparison of 1929 Correspondent Distribution of Closed and Surviving Banks } \\
\hline & \multicolumn{3}{|c|}{$\begin{array}{l}\text { Non-Fed State Banks } \\
\text { and Trust Companies }\end{array}$} & \multicolumn{3}{|c|}{$\begin{array}{c}\text { Fed Member State Banks } \\
\text { and Trust Companies } \\
\end{array}$} & \multicolumn{3}{|c|}{ National Banks } & \multicolumn{3}{|c|}{ All Banks } \\
\hline & Closed & Surv. & Diff & Closed & Surv. & Diff & Closed & Surv. & Diff & Closed & Surv. & Diff \\
\hline \# of Banks & 9,719 & 7,372 & - & 604 & 570 & - & 3,381 & 4,401 & - & 13,704 & 12,343 & - \\
\hline Avg. \% Any Fed Bank or Branch City Correspondents & $68.4 \%$ & $69.9 \%$ & $1.5 \%$ & $87.6 \%$ & $86.4 \%$ & $-1.2 \%$ & $81.8 \%$ & $85.7 \%$ & $3.9 \%$ & $73.0 \%$ & $76.8 \%$ & $3.8 \%$ \\
\hline Avg. \% New York Correspondents & $16.9 \%$ & $18.6 \%$ & $1.7 \%$ & $30.3 \%$ & $32.5 \%$ & $2.2 \%$ & $26.7 \%$ & $29.0 \%$ & $2.3 \%$ & $20.2 \%$ & $23.3 \%$ & $3.1 \%$ \\
\hline Avg. \% Chicago Correspondents & $13.4 \%$ & $11.0 \%$ & $-2.3 \%$ & $14.5 \%$ & $11.8 \%$ & $-2.7 \%$ & $14.2 \%$ & $10.1 \%$ & $-4.2 \%$ & $13.7 \%$ & $10.7 \%$ & $-3.0 \%$ \\
\hline Avg. \% St Louis Correspondents & $4.7 \%$ & $4.2 \%$ & $-0.6 \%$ & $4.8 \%$ & $3.0 \%$ & $-1.8 \%$ & $3.3 \%$ & $3.7 \%$ & $0.4 \%$ & $4.4 \%$ & $3.9 \%$ & $-0.4 \%$ \\
\hline Avg. \% Non-CRC Fed City Correspondents & $33.4 \%$ & $36.1 \%$ & $2.6 \%$ & $38.0 \%$ & $39.0 \%$ & $1.0 \%$ & $37.6 \%$ & $42.9 \%$ & $5.4 \%$ & $34.8 \%$ & $38.9 \%$ & $4.1 \%$ \\
\hline Avg. \% Correspondents in District's Fed Cities & $40.7 \%$ & $42.9 \%$ & $2.1 \%$ & $45.1 \%$ & $45.7 \%$ & $0.6 \%$ & $42.1 \%$ & $45.6 \%$ & $3.5 \%$ & $41.3 \%$ & $43.9 \%$ & $2.7 \%$ \\
\hline Avg. Distance to Correspondents (in Miles) & 260.5 & 221.1 & -39.4 & 353.1 & 293.4 & -59.7 & 410.9 & 302.6 & -108.4 & 301.5 & 253.4 & -48.1 \\
\hline
\end{tabular}

Notes: Tables provides the summary statistics for each variable for the group of banks identified in the column heading. The top panel pertains to banks that survived from 1929 through 1940. The bottom panel pertains to all banks present in 1929. Fed membership of observed state bank and trust companies is as of 1929. Fed membership of correspondents is as of the specified year (i.e., 1929 or 1940 for the top panel and 1929 in the bottom panel). With the exception of the first and the last, each of the rows provides the average fraction of total correspondents that take the particular characteristic described. See notes to Table 5 for other definitions. 
Table A.1: City-Level Centrality Statistics (1900-1940)

\begin{tabular}{|c|c|c|c|c|c|}
\hline & \multicolumn{5}{|c|}{ Eigenvector Centrality } \\
\hline & 1900 & 1910 & 1919 & 1929 & 1940 \\
\hline Mean & $1.79 \%$ & $0.78 \%$ & $0.63 \%$ & $0.64 \%$ & $0.91 \%$ \\
\hline New York & $124.53 \%$ & $87.88 \%$ & $77.66 \%$ & $79.04 \%$ & $96.86 \%$ \\
\hline Chicago & $56.81 \%$ & $39.30 \%$ & $41.05 \%$ & $46.98 \%$ & $49.00 \%$ \\
\hline St Louis & $24.79 \%$ & $16.23 \%$ & $14.18 \%$ & $13.95 \%$ & $17.40 \%$ \\
\hline Boston & $12.99 \%$ & $5.55 \%$ & $5.88 \%$ & $7.48 \%$ & $12.57 \%$ \\
\hline Philadelphia & $17.45 \%$ & $11.10 \%$ & $10.70 \%$ & $12.78 \%$ & $19.53 \%$ \\
\hline Cleveland & $7.13 \%$ & $4.07 \%$ & $4.66 \%$ & $7.19 \%$ & $7.91 \%$ \\
\hline Richmond & $4.34 \%$ & $3.15 \%$ & $4.52 \%$ & $4.96 \%$ & $5.98 \%$ \\
\hline Atlanta & $4.74 \%$ & $3.45 \%$ & $4.03 \%$ & $5.18 \%$ & $8.54 \%$ \\
\hline Minneapolis & $20.90 \%$ & $12.17 \%$ & $13.55 \%$ & $12.03 \%$ & $16.88 \%$ \\
\hline Kansas City & $13.42 \%$ & $11.58 \%$ & $12.87 \%$ & $11.83 \%$ & $12.92 \%$ \\
\hline Dallas & $3.90 \%$ & $3.76 \%$ & $4.90 \%$ & $5.63 \%$ & $8.86 \%$ \\
\hline San Francisco & $9.55 \%$ & $5.21 \%$ & $6.92 \%$ & $8.18 \%$ & $10.46 \%$ \\
\hline All Fed Branches & $5.16 \%$ & $3.05 \%$ & $3.28 \%$ & $4.02 \%$ & $6.04 \%$ \\
\hline \multirow[t]{3}{*}{ Top 100 Non-Fed Cities } & $3.02 \%$ & $1.66 \%$ & $1.59 \%$ & $1.94 \%$ & $2.69 \%$ \\
\hline & \multicolumn{5}{|c|}{ Betweenness Centrality } \\
\hline & 1900 & 1910 & 1919 & 1929 & 1940 \\
\hline Mean & $0.02 \%$ & $0.01 \%$ & $0.01 \%$ & $0.01 \%$ & $0.02 \%$ \\
\hline New York & $72.31 \%$ & $64.32 \%$ & $56.96 \%$ & $50.19 \%$ & $50.34 \%$ \\
\hline Chicago & $19.18 \%$ & $24.38 \%$ & $25.15 \%$ & $27.55 \%$ & $23.13 \%$ \\
\hline St Louis & $6.93 \%$ & $10.51 \%$ & $9.35 \%$ & $9.02 \%$ & $7.90 \%$ \\
\hline Boston & $5.07 \%$ & $2.29 \%$ & $2.13 \%$ & $2.87 \%$ & $3.02 \%$ \\
\hline Philadelphia & $3.72 \%$ & $3.81 \%$ & $3.61 \%$ & $4.64 \%$ & $4.49 \%$ \\
\hline Cleveland & $0.36 \%$ & $0.35 \%$ & $0.49 \%$ & $1.34 \%$ & $1.09 \%$ \\
\hline Richmond & $0.12 \%$ & $0.59 \%$ & $1.18 \%$ & $1.55 \%$ & $1.30 \%$ \\
\hline Atlanta & $0.20 \%$ & $0.33 \%$ & $0.38 \%$ & $0.79 \%$ & $1.64 \%$ \\
\hline Minneapolis & $5.00 \%$ & $7.37 \%$ & $9.47 \%$ & $8.68 \%$ & $10.04 \%$ \\
\hline Kansas City & $2.18 \%$ & $5.29 \%$ & $8.77 \%$ & $8.57 \%$ & $8.24 \%$ \\
\hline Dallas & $0.04 \%$ & $0.56 \%$ & $1.03 \%$ & $1.70 \%$ & $2.70 \%$ \\
\hline San Francisco & $1.53 \%$ & $0.86 \%$ & $0.96 \%$ & $1.12 \%$ & $1.64 \%$ \\
\hline All Fed Branches & $0.35 \%$ & $0.56 \%$ & $0.60 \%$ & $0.88 \%$ & $1.06 \%$ \\
\hline \multirow[t]{3}{*}{ Top 100 Non-Fed Cities } & $0.07 \%$ & $0.08 \%$ & $0.11 \%$ & $0.14 \%$ & $0.17 \%$ \\
\hline & \multicolumn{5}{|c|}{ Degree Centrality } \\
\hline & 1900 & 1910 & 1919 & 1929 & 1940 \\
\hline Mean & $0.09 \%$ & $0.04 \%$ & $0.04 \%$ & $0.03 \%$ & $0.05 \%$ \\
\hline New York & $75.49 \%$ & $62.62 \%$ & $55.01 \%$ & $47.63 \%$ & $48.21 \%$ \\
\hline Chicago & $32.44 \%$ & $30.62 \%$ & $30.68 \%$ & $30.18 \%$ & $26.07 \%$ \\
\hline St Louis & $13.93 \%$ & $13.69 \%$ & $11.77 \%$ & $10.14 \%$ & $9.29 \%$ \\
\hline Boston & $7.36 \%$ & $3.26 \%$ & $3.25 \%$ & $3.63 \%$ & $4.78 \%$ \\
\hline Philadelphia & $9.25 \%$ & $7.38 \%$ & $6.95 \%$ & $7.19 \%$ & $7.96 \%$ \\
\hline Cleveland & $2.64 \%$ & $1.92 \%$ & $2.42 \%$ & $2.92 \%$ & $2.57 \%$ \\
\hline Richmond & $1.20 \%$ & $1.55 \%$ & $3.02 \%$ & $2.84 \%$ & $2.53 \%$ \\
\hline Atlanta & $1.36 \%$ & $1.56 \%$ & $2.15 \%$ & $2.30 \%$ & $3.28 \%$ \\
\hline Minneapolis & $12.28 \%$ & $10.89 \%$ & $12.92 \%$ & $10.62 \%$ & $11.19 \%$ \\
\hline Kansas City & $6.89 \%$ & $9.31 \%$ & $12.72 \%$ & $10.53 \%$ & $9.41 \%$ \\
\hline Dallas & $0.61 \%$ & $1.81 \%$ & $3.03 \%$ & $3.29 \%$ & $4.50 \%$ \\
\hline San Francisco & $4.09 \%$ & $2.54 \%$ & $3.54 \%$ & $3.18 \%$ & $3.04 \%$ \\
\hline All Fed Branches & $1.45 \%$ & $1.37 \%$ & $1.64 \%$ & $1.78 \%$ & $2.00 \%$ \\
\hline Top 100 Non-Fed Cities & $0.35 \%$ & $0.29 \%$ & $0.38 \%$ & $0.41 \%$ & $0.45 \%$ \\
\hline
\end{tabular}

Notes: Table provides centrality scores for each year. Bank-level data are aggregated to the city-level before calculating the statistics. Intra-city connections are excluded from the calculation. Degree centrality refers to the percentage of other cities in a year that a city is connected to. Eigenvector centrality is normalized to total 100 for all cities in a year and is reported in percentage points. Betweenness centrality is defined as the percentage of paths between all city-pairs that include a given city. "Top 100 Non-Fed Cities" is based on city population in 1910 . 
Table A.2: Interbank Networks Statistics for Clearinghouse Cities (1900-1919)

\begin{tabular}{|c|c|c|c|c|c|}
\hline & \multicolumn{5}{|c|}{ Never Had Clearinghouse } \\
\hline & 1900 & 1910 & 1919 & $\Delta 1900-10$ & $\Delta 1910-20$ \\
\hline Avg. \# of Respondents Per City & 0.30 & 0.90 & 2.42 & 0.60 & 1.52 \\
\hline Avg. \# of Correspondents Per City & 3.79 & 5.26 & 7.59 & 1.47 & 2.34 \\
\hline \multirow[t]{3}{*}{ Avg. Eigenvector Centrality Per City } & 0.0196 & 0.0196 & 0.0195 & 0.0000 & -0.0001 \\
\hline & \multicolumn{5}{|c|}{ Clearinghouse Existed Before 1890} \\
\hline & 1900 & 1910 & 1919 & $\Delta 1900-10$ & $\Delta 1910-20$ \\
\hline Avg. \# of Respondents Per City & 368.27 & 714.55 & 1000.96 & 346.29 & 286.41 \\
\hline Avg. \# of Correspondents Per City & 56.55 & 70.55 & 85.76 & 14.00 & 15.20 \\
\hline \multirow[t]{3}{*}{ Avg. Eigenvector Centrality Per City } & 0.0944 & 0.0941 & 0.1007 & -0.0003 & 0.0067 \\
\hline & \multicolumn{5}{|c|}{ Clearinghouse Existed 1890-1900 } \\
\hline & 1900 & 1910 & 1919 & $\Delta 1900-10$ & $\Delta 1910-20$ \\
\hline Avg. \# of Respondents Per City & 10.05 & 26.14 & 58.50 & 16.09 & 32.36 \\
\hline Avg. \# of Correspondents Per City & 17.73 & 21.59 & 28.41 & 3.86 & 6.82 \\
\hline \multirow{3}{*}{ Avg. Eigenvector Centrality Per City } & 0.0324 & 0.0322 & 0.0328 & -0.0002 & 0.0005 \\
\hline & \multicolumn{5}{|c|}{ Clearinghouse Established 1900-1910 } \\
\hline & 1900 & 1910 & 1919 & $\Delta 1900-10$ & $\Delta 1910-20$ \\
\hline Avg. \# of Respondents Per City & 5.92 & 23.05 & 51.98 & 17.13 & 28.94 \\
\hline Avg. \# of Correspondents Per City & 13.67 & 20.88 & 26.94 & 7.20 & 6.06 \\
\hline \multirow[t]{3}{*}{ Avg. Eigenvector Centrality Per City } & 0.0300 & 0.0310 & 0.0321 & 0.0010 & 0.0012 \\
\hline & \multicolumn{5}{|c|}{ Clearinghouse Established 1910-1919 } \\
\hline & 1900 & 1910 & 1919 & $\Delta 1900-10$ & $\Delta 1910-20$ \\
\hline Avg. \# of Respondents Per City & 4.14 & 11.75 & 26.31 & 7.61 & 14.56 \\
\hline Avg. \# of Correspondents Per City & 8.48 & 13.45 & 18.86 & 4.97 & 5.40 \\
\hline Avg. Eigenvector Centrality Per City & 0.0277 & 0.0278 & 0.0293 & 0.0001 & 0.0016 \\
\hline
\end{tabular}

Notes: Table provides average statistics for groups of cities listed in column headings. Only cities that had at least one bank present from 1900 through 1940 are included in the calculations. 
Figure A.1: Correlation Between Change In Eigenvector Centrality and Percentage Change in Banks (1929-1940) Panel A: All Cities

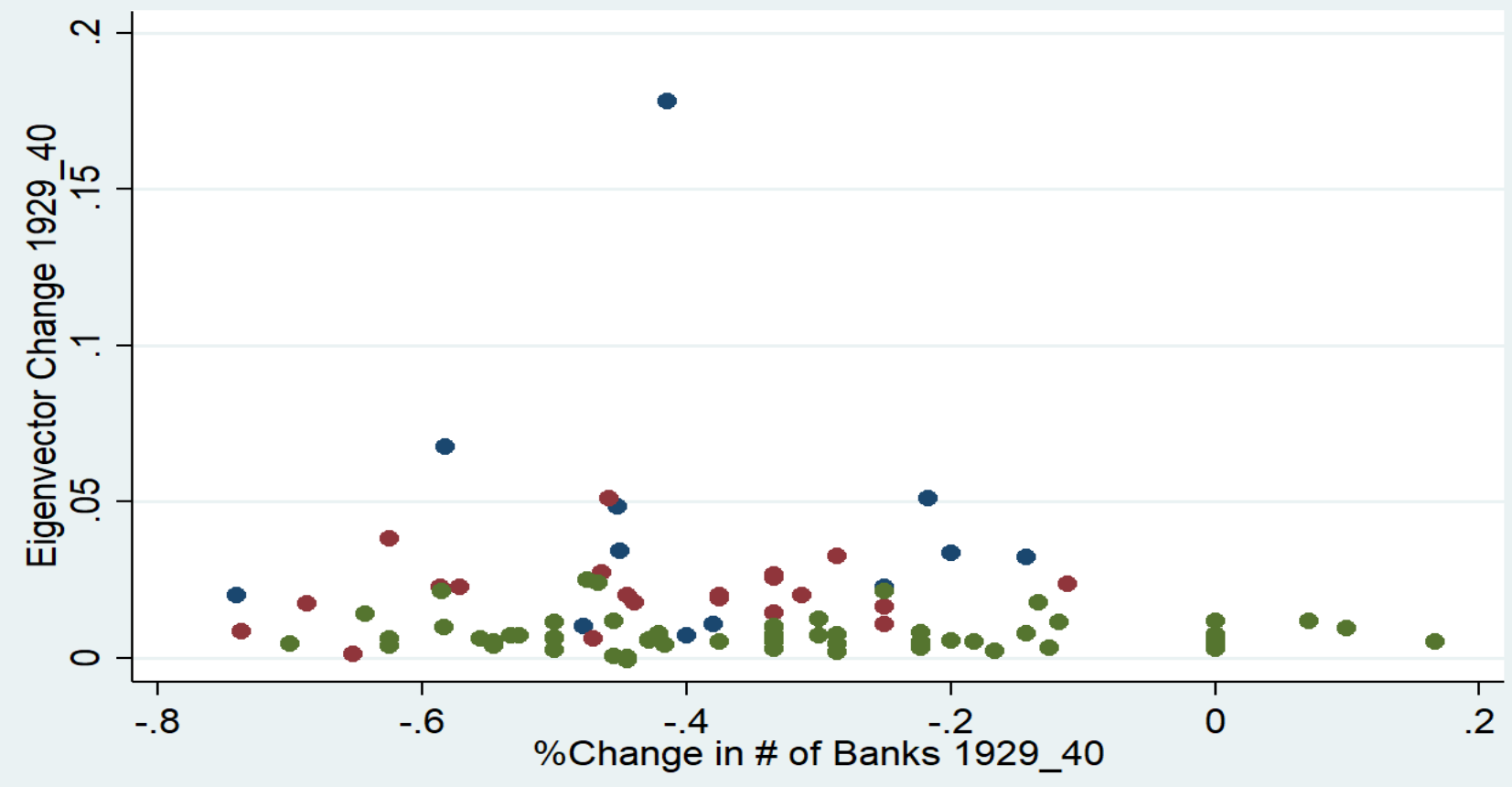

Panel B: Removing New York

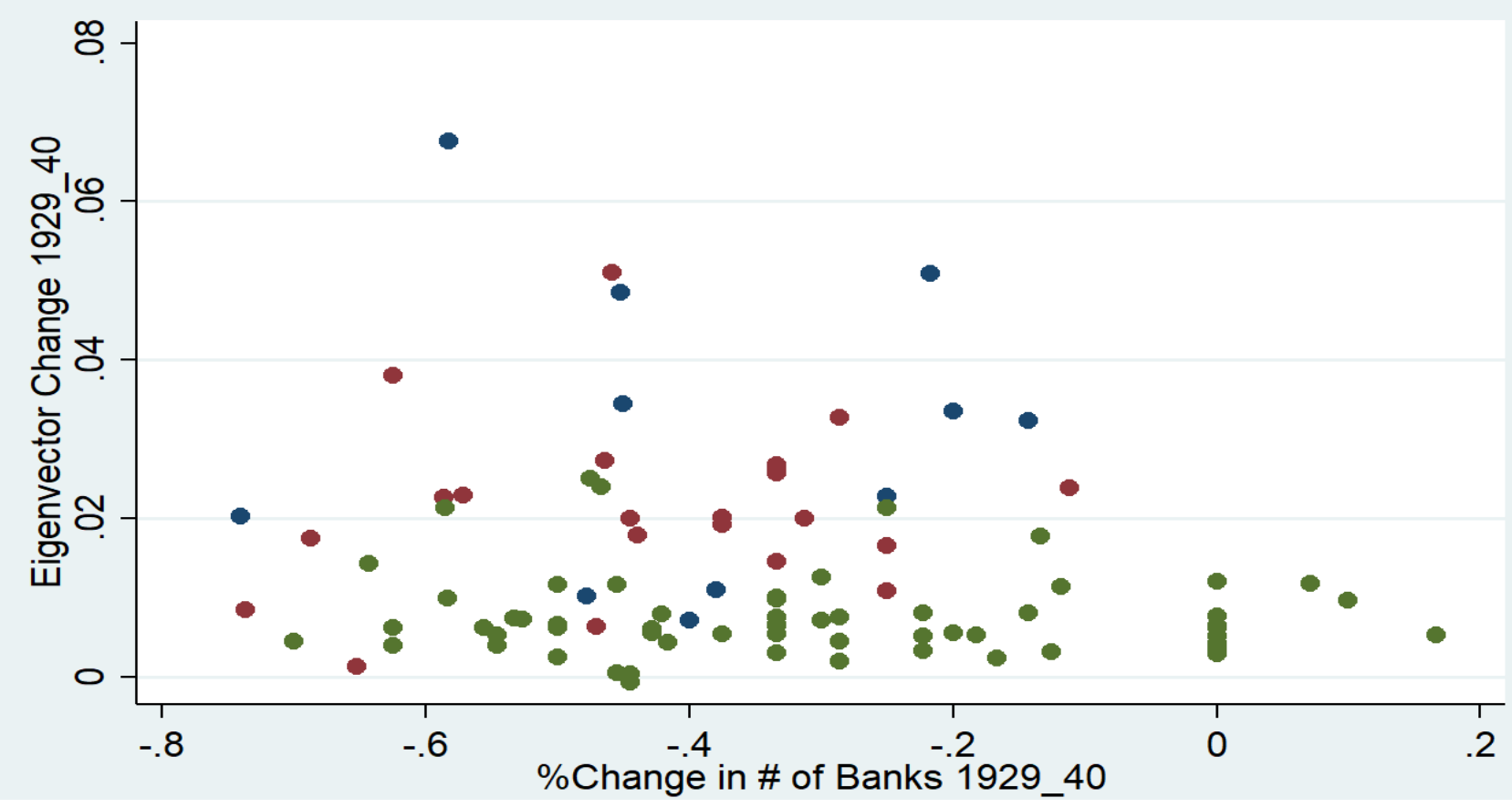

Notes: Figures display the change in each city's eigenvector centrality during 1929-1940 against the percentage change in number of banks. Only Fed Cities and other cities among the largest 100 cities are included. Blue dots denote Fed Reserve Bank cities, red dots denote Fed branch cities, and green dots denote all other cities. 
Figure A.2: Fraction of Banks Closed During Great Depression As A Fraction of Closed Correspondents

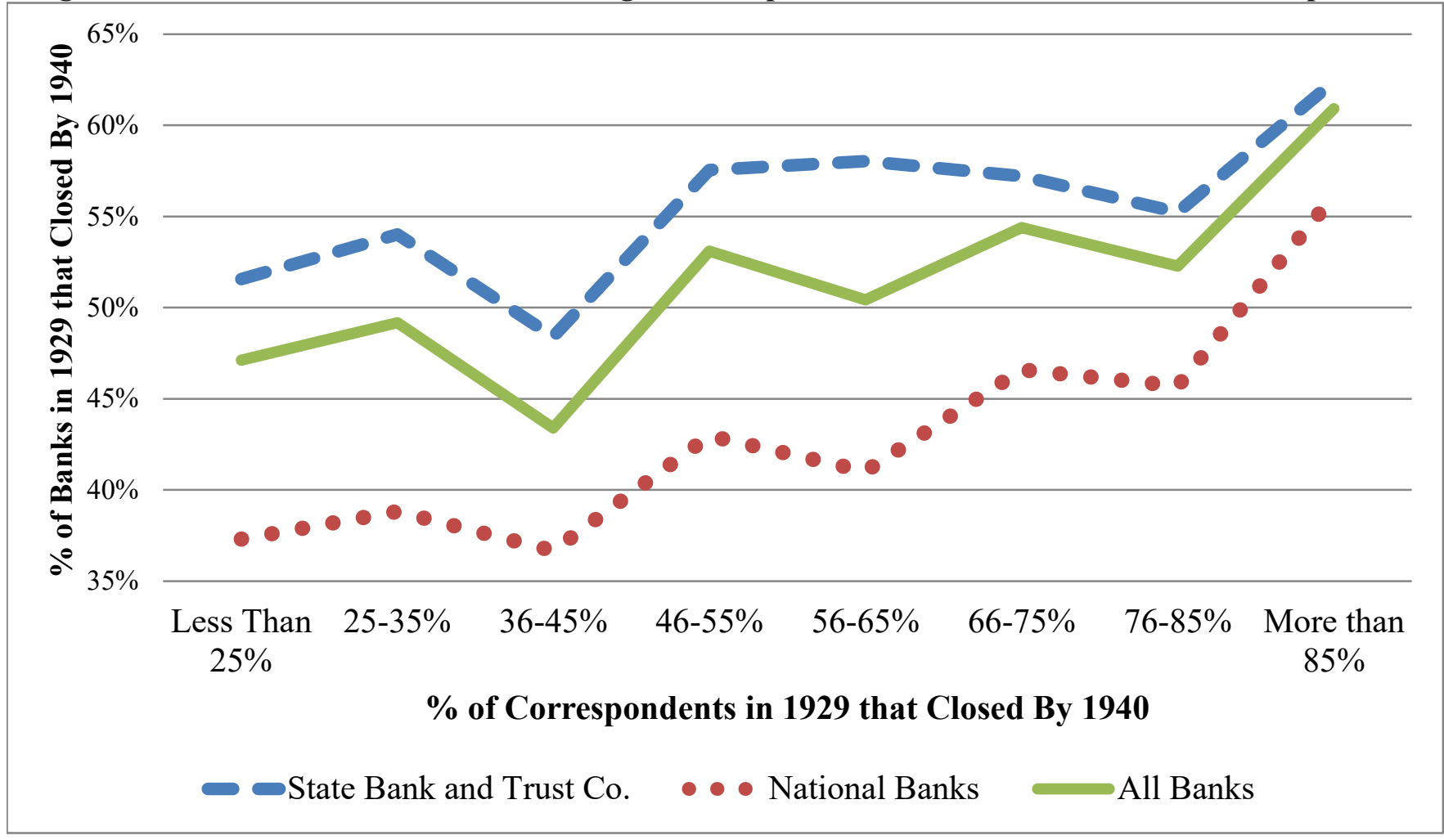

Notes: Figures provides the percent of banks in 1929 that closed before 1940 as a function of the percent of their correspondents in 1929 that closed before 1940. 